\title{
Corporate Social Responsibility and Latin American firm performance
}

\author{
Chiara Amini, \\ London Metropolitan University, London Metropolitan Business School, 84 Moorgate, London, EC2M 6SQ , \\ UK; c.amini@londonmet.ac.uk
}

Silvia Dal Bianco,

London Metropolitan University,London Metropolitan Business School, 84 Moorgate, London, EC2M 6SQ, UK; s.dalbianco@londonmet.ac.uk

Abstract (structured)

\begin{abstract}
Purpose - The purpose of this paper is to analyse the impact of Corporate Social Responsibility (CSR) on firm performance in six Latin American economies. Firm performance comprises the following five distinct dimensions: firm turnover, labour productivity, innovativeness, product differentiation and technological transfer. The countries under scrutiny are Argentina, Bolivia, Chile, Colombia, Ecuador and Mexico.

Design/methodology/approach - Propensity Score Matching techniques are employed to identify the causal effect of CSR on firm performance. To this end, the World Bank Enterprise Survey (2006 wave) is employed. This dataset collects relevant firm-level data

Findings - CSR has a positive impact on the outcome variables analysed, suggesting that corporate goals are compatible with conscious business operations. The results also vary across countries.

Research limitations/implications - The pattern that emerges from the analysis seems to suggest that the positive effects of CSR depend on a country's stage of industrialisation. In particular, the less developed the economy, the wider the scope of CSR. Nonetheless, the relationship among conscious business operations, firm performance and countries' levels of development is not directly tested in the present work.

Practical implications - The main practical implication of the study is that Latin American firms should adopt CSR. This is because corporate responsible practices either improve firm performance or are not shown to have a detrimental effect.

Social implications - The major policy implication is that emerging countries' governments as well as international organisations should provide meaningful incentives for CSR adoption.

Originality/value - The paper makes three major original contributions. First, it furnishes new descriptive evidence on CSR practices in Latin America. Second, it employs a broader and novel definition of firm performance intended to capture business dynamics in developing countries, as well as to overcome data limitations. Finally, it reassesses and extends the empirical evidence on the impact of CSR on firm performance.

Keywords - Corporate Social Responsibility, Firm Performance, Propensity Score Matching, Latin America

Paper type - Research paper
\end{abstract}




\section{Introduction}

In the past decade, both business practitioners and policy makers have paid increasing attention to firms' socially responsible practices because these are of interest not only to firms but also to society as a whole (McWilliams and Siegel, 2000; Margolis and Walsh, 2003; Orlitzky et al 2003). Visser (2008) defines Corporate Social Responsibility (henceforth CSR) as "the formal and informal ways in which business makes a contribution to improving the governance, social, ethical, labour and environmental conditions of the developing countries in which they operate, while remaining sensitive to prevailing religious, historical and cultural contexts". One of the main issues in this context concerns the "global credibility" of CSR and, thus, the integration of socially and environmentally conscientious practices into the ordinary business of developing countries' firms (see, for example, Adeyeye, 2011; Berliner and Prakash, 2014; and Moratis, 2015)

To date, the main research efforts on CSR have concentrated on developed countries (Orlitzky et al, 2003; Jamali, 2008; Bird et. al., 2007). This is primarily because CSR originated in Western companies and information on such firms' practices is mainly available in advanced economies. However, the pressures to adopt socially responsible practices have dramatically increased in emerging markets (Visser, 2008). On the one hand, this is due to the effects that developing countries' industrialisation is likely to have on their environments (Grossman and Krueger, 1995; Dasguptaet. al, 2002) as well as on their social norms (Lall, 2002). On the other, it is due to the fact that CSR is now considered to be intertwined with poverty alleviation and sustainable development (Blowfield, 2005 and Moon, 2007). 
Historically, firms in both developed and developing countries have had a mixed reaction to the increasing popularity of CSR. While some firms have devoted more resources to social and environmental activities, others have resisted the trend because of the concern that growing expenditure in this area may negatively affect the economic viability of the business. It is therefore crucial to assess how CSR affects firm performance in laggard economies and whether the goals of private enterprises can be aligned with those of conscientious business as well as with sustainable development. Empirical research on developed countries has analysed the impact of CSR on firms' performance, but the results have been mixed. The conflicting empirical findings may be the consequences of using different proxies for CSR or different samples. However, with the sole exception of Cheng and Shan (2009), the great majority of studies have failed to consider that CSR is likely to be endogenous. That is, firms with better performances or with certain characteristics are systematically more likely to adopt CSR practices. Hence any empirical exercise that does not tackle the endogeneity issue provides non-consistent results.

The aim of this paper is to investigate the causal effect of CSR on firm performance in six Latin American middle-income economies, taking into account the likely endogeneity of CSR as well as the peculiarities of business dynamics in developing countries.

More in detail, we take advantage of the 2006 World Bank Enterprise Surveys (WEBS) on Bolivia, Argentina, Chile, Colombia, Mexico and Ecuador, and we employ Propensity Score Matching techniques (henceforth PSM) to conduct a consistent assessment of the CSR/firm performance nexus. ${ }^{1}$ In particular, PSM enable us to adjust for observable differences in

\footnotetext{
${ }^{1}$ In employing the term "developing countries" we follow the World Bank's definition according to which the set of developing countries encompasses all Low and Middle income economies. In particular, in 2006, three of our sampled countries were classified as Lower Middle Income (i.e. Bolivia, Colombia and Ecuador) while the rest were Upper Middle Income (i.e. Argentina, Chile and Mexico).
} 
characteristics between firms that adopt CSR practices and those that do not, thus making an adequate 'like-for-like' comparison possible.

Our intention to study CSR in the Latin American context is motivated by the observation that, although Latin America is the developing region least covered in terms of CSR research, there is an increasing trend of CSR adoption by Latin American firms (Visser, 2008). Hence a better understanding of the impact that CSR has on firm performance appears extremely important.

This study makes three main contributions. First, we provide new descriptive evidence on CSR in Latin America. Second, we move beyond the narrow definition of firm performance as financial success. In particular, in order to highlight the peculiarities of business dynamics in developing countries, as well as to overcome data limitations, we formulate five distinct theoretical hypotheses on the CSR/performance link, and we examine the causal effects of socially responsible practices on firm turnover, labour productivity, innovativeness, product differentiation and technological transfer. Third, overall, our work reassesses and extends the empirical evidence on the impact of CSR on firm performance.

Turning to the results, our descriptive analysis shows that the majority of firms engage in CSR; and that environmental practices, such as water optimisation programmes, are the most common, followed by those aimed at supporting communities as well as workers. Moreover, we document that firms engage in more than one type of CSR simultaneously: that is, the majority of the firms that have environmental programmes also have labour or community supportive policies. Finally, we highlight that CSR adopters have distinct intrinsic characteristics. In particular, such firms tend to be large, well-established, engaged in Research and Development, and foreign owned.

In regard to the matching exercise, overall our results provide supportive evidence for the theoretical hypotheses that we have formulated. They thus show that corporate goals are 
compatible with conscious operations in developing countries. However, it should also be noted that our findings exhibit great variability across countries. In particular, we find that poorer countries, such as Bolivia and Colombia, display the highest numbers of links between CSR and the outcome variables analysed, while in the richer ones, such as Mexico and Argentina, CSR has a sizeable effect only on innovativeness. Finally, no effect is found in Chile, the most developed country in our sample. Hence, it seems advisable for governments and international organisations to provide meaningful incentives for CSR adoption, especially in least developed economies.

The remainder of the paper is organised as follows. Section 2 briefly reviews the relevant literature. Section 3 discusses the methodology. The fourth part presents the data employed and provides a preliminary analysis by considering some descriptive statistics. Finally we discuss the results of the matching exercise, and we conclude with final remarks and policy implications.

\section{Literature Review}

In this section we first consider the literature on CSR practices in developing countries. We then explore current theory on the relationship between CSR and firm performance, and we assess the available empirical evidence based on the experiences of advanced economies. Finally, we discuss the hypotheses to be tested in the remainder of the paper in light of the relevant theoretical literature.

\subsection{CSR in developing regions: coverage and evidence}


Most of the literature on CSR and firm performance in developing countries is qualitative in nature, and it is often based on case studies.

In terms of regional coverage, a large part of the literature has focused on Asia (Visser, 2008). ${ }^{2}$ A comparative analysis by Welford (2005) shows, perhaps unsurprisingly, that Asian countries, such as Hong Kong, Malaysia and Thailand, consistently underperform developed countries on several aspects of CSR. However, it is important to note that there is some regional variation in CSR reporting: $75 \%$ of large Indian companies have some CSR policies compared to only $32 \%$ of firms in Malaysia and $30 \%$ in the Philippines. Finally, Luken and Stares (2005) use the United Nations information on 22 small and medium enterprises in four developing Asian countries to show that environmental and social practices are correlated with financial savings, environmental, social and product improvement.

Turning to studies investigating CSR practices in Africa, the majority of them concentrate on South Africa and Nigeria. Moreover, most of the studies focus on critical sectors such as agriculture (e.g. Blowfield, 2003), mining (e.g. Kapelus, 2002) and petrochemicals (e.g. Acutt et al., 2004). Finally, CSR debates in the region have been centred on ethical issues related to apartheid, colonialism and corruption.

For what concerns Latin America, which is the continent of interest for our study, Visser (2008) points out that, among all developing regions, Latin America is the one least covered in terms of CSR research. Moreover, the available evidence is concentrated on Argentina (e.g. Newell and Muro, 2006), Brazil (e.g. Vivarta and Canela, 2006) and Mexico (e.g. Weyzig, 2006). Nevertheless, the most recent literature reports that CSR is increasing in the region. For example, Araya (2006) documents that $34 \%$ of large companies publish a report on sustainability. Further, Vives (2006) provides insights on the importance of specific CSR

\footnotetext{
${ }^{2}$ For instance, Zhuang and Wheale (2004) on China, Blowfiel?d (2004) on Indonesia, Lund-Thomsen (2004) on Pakistan, and Kaufmann et al. (2004) on Thailand.
} 
practices in small and medium enterprises (SMEs) in eight Latin American countries. He finds that most CSR by SMEs is focused on internal activities, such as employee welfare, whereas philanthropic and environmental activities are less common. Finally, Amini and Dal Bianco (2015) show that Latin American firms which engage in environmental or community projects are no less efficient than firms that do not adopt such practices. They thus suggest that corporate goals, such as productivity, are compatible with conscious operations.

2.2 CSR and firm performance: theoretical background and evidence from developed countries

Research on CSR is mainly focused on developed countries, or on the activities of Western multinational companies (MNC) in emerging markets (Muller and Kolk, 2008).

The theoretical literature has formulated two competing hypotheses concerning the effect of CSR on firm performance. The first is called the "social impact hypothesis"; the second one the "shift of focus view". While the former claims that CSR has a positive effect on firms' financial performance, the latter suggests the opposite.

According to the social impact hypothesis, three channels may explain the positive relationship between CSR and firm performance. They are: improving employee productivity by providing a better working environment (Turban and Greening, 1997); increasing managerial know-how and thus enhancing organizational efficiency (Orlitzky et al., 2003); increasing social reputation, trust (Bowman and Haire, 1975), brand image and product competitiveness (Porter and Van derLinde, 1995). This last channel works principally through the media, which make firms responsible to stockholders and consumers (Chen and Shang, 2009). 
The shift of focus view instead argues that activities such as building employee and community relationships and providing environmental protection cause a shift of focus from the traditional corporate goals to the interests of a wider set of stakeholders which increases firms' costs (Becchetti, Ciciretti and Hasan, 2007). Moreover, some studies also argue that corporations engaged in CSR activities have lower market competitiveness and worse performance because they may use resources inefficiently (Friedman, 1970), limit product developments (Bragdon and Marlin, 1972) and push unprofitable social activities (Aupperle et al., 1985; Vance, 1975; Ullmann, 1985).

Turning to the empirical literature, the bulk of existing studies examine the relationship between some measure of CSR and the long-term firm performance, which is proxied by accounting or financial measures of profitability. Typically, these studies estimate the effect of CSR by regressing firm performance on corporate social performance and various control variables. Firm performance is usually associated with firm financial performance. It is consequently measured in terms of price per share, return on assets or on equity (Orlitzky et al., 2003). Four common ways to measure CSR are: (a) disclosures, such as annual reports, letters to shareholders and other corporate disclosures to the public; (b) reputation ratings; (c) social audits; and (d) managerial principles and values (Orlitzky et al., 2003).

Existing empirical studies on the CSR/firm performance nexus in advanced economies report mixed results. For example, Newgren et al. (1985) and Brammer et al. (2005a) find that firms that engage in environment protection and community relationships have significantly lower stock returns. In contrast, Cochran and Wood (1984), Waddock and Graves (1997), and Tsoutsourz (2004) find that the CSR reputation index positively affects firms' performance. Further, Orlitzky et al (2003) conduct a meta-analysis of 52 studies and show that social responsibility, and to a lesser extent environmental responsibility, is likely to have a positive effect on firm performance. 
Finally, the empirical evidence on CSR and firm financial performance remains inconclusive even when the likely endogeneity of CSR practices is taken into account, as in the recent work by Cheng and Shang (2009). In particular, these authors employ propensity score matching to tackle the endogeneity issues, and they investigate the relationship between CSR and financial performance by using Taiwanese firms' quarterly data from 2005 to 2006 . In this instance, CSR is measured by the reputation rating given by the Global View Monthly, which is a leading commercial magazine in Taiwan. Firm financial performance, instead, is proxied by the return on investment and equity, pre-tax income to net sales, gross profit to net sales and earnings per share. Cheng and Shang's (2009) results show that firms engaging in CSR activities obtain significantly higher values of pre-tax income and profit margin, but there is no significant difference between returns on investment and earnings per share. Although admitting that this non-univocal result may be due to the matching exercise, Chen and Shang's (2009) interpretation is that CSR is not detrimental to firm performance, in the sense that it never has a significant and negative effect.

\subsection{Broadening the concept of firm performance and testable hypotheses}

So far our literature review has highlighted two main facts. First, the bulk of the research on the relationship between CSR and firm performance is focused on developed economies' experiences. Second, the available evidence on that link is inconclusive because the empirical results have been mixed. Since our goal is to shed light on the impact of CSR on aspects of the firm that are crucial for the process of development, this paper moves beyond the narrow definition of firm performance as financial success. Thus, in order to take developing countries' business dynamics into account, as well as to deal with current data limitations, we explore five dimensions of firm performance: firm turnover, labour productivity, 
innovativeness, product differentiation, and technological transfer. For each dimension, we formulate five distinct theoretical hypotheses which can shed some light on how CSR affects the performance of firms in developing countries.

Starting with firm turnover, this variable is measured by firms' revenues. Our consideration of firm turnover as a firm performance indicator has a twofold rationale. First, we assume that firms' managements aim to maximise profits (Jensen, 1988) but, as we lack data on standard financial performance indicators, we rely on sales data ${ }^{3}$. Finally, a possible (positive) relationship between CSR and revenues can be justified in light of the traditional demand and supply model of McWilliams and Siegel (2001). On the demand side, the consumers and other stakeholders demand CSR and its attributes. On the supply side, firms that are willing to satisfy such a demand must devote resources to CSR. Eventually, such firms will experience an increase in revenues, as prediceted by Jones (1995) or McWilliams and Siegel (2010). These considerations lead to the following hypothesis:

Hypothesis 1: CSR has a positive impact on firms' revenues.

Turning to labour productivity, this variable is defined as the sales per employee ratio. This measure has been extensively used in the literature (see the recent review by Sanchez and Benito-Hernandez, 2013). Following the arguments put forward by Stuebs and Sun (2010), we presume that CSR improves business reputation and that good business reputation can enhance labour productivity, for example because socially responsible firms attract and retain more skilled employees (Lado and Wilson, 1994; Turban and Greening, 1997) or because CSR practices are often directly related to promoting employee empowerment (McWilliams et al., 2006). Another possible channel through which CSR can boost labour productivity is

\footnotetext{
${ }^{3}$ This approach is similar to Baumol (1962) and McGuire et al. (1962)
} 
the one related to social capital building and lower employee turnover (Russo and Perrini, 2010).

Thus, our next hypothesis is:

Hypothesis 2: CSR has a positive impact on firms' labour productivity.

In regard to firm innovativeness, according to Moore (2005), CSR and ethical practices can be drivers of innovation because they favour the formation of innovation networks, as well as confidence in cooperative processes. More recently, Brodhag (2013) has intertwined CSR practices with the classic debate on innovation driving forces (i.e. "market pull" versus "technology push"). His review highlights that responsible practices can boost innovation from both the pull perspective, as in the case of sustainability-oriented innovations (Hansen et al., 2009), and from the push one, as when innovation is regulation-induced (Porter and Van derLinde, 1995; Ashford and Hall, 2011). Thus, our third hypothesis is:

Hypothesis 3: CSR is a driving force for innovation; hence it has a positive effect on firms' innovative activities.

Before turning to the next hypothesis, we point out that we measure firm innovativeness with a dummy variable taking the value of one if the firm invests in Research and Development (henceforth RnD) within the establishment or through a third party. The inclusion of Outdoor $\mathrm{RnD}$ is motivated by the nature of technological progress in developing countries, which is characterised by the innovation-imitation dynamic (DalBianco, 2010; 2015). This point will be fully clarified in the discussion of Hypothesis (5). 
We then explore the relationship between CSR and product differentiation or RnD intensity, which is measured as the ratio of $\mathrm{RnD}$ expenditures to sales. This is motivated by the argument of McWilliams and Siegel (2001) that CSR features embedded in firm products can be conceived as new products. Thus, our testable hypothesis is:

Hypothesis 4: CSR has a positive impact on the level of product differentiation.

Finally, we explicitly assume that technological advances in developing countries are related to the transfer of ideas from the technological leaders (see Nelson and Phelps (1966) and Baumol (1986) for seminal contributions). In particular, drawing on Griliches (1979) and on the results of Griffith et al. (2006), we envisage a link between firm innovative activities and outdoor RnD. Then, as in the discussion related to Hypotheses (3) and (4), we assess the relationship between CSR and technological transfer, measured as the third party-RnD expenditures to sales ratio. Hence, our last hypothesis is:

Hypothesis 5: CSR has a positive effect on technological transfer, that is, the third-party RnD to sales ratio

\section{Methodology}

3.1 The causal effect of CSR on firm performance: estimable equations and methodological issues

The primary goal of our analysis is to evaluate the causal effect of CSR adoption on different measures of firm performance by using observational data (i.e. non-experimental data). 
Following Becerril and Abdulai (2010), we employ an empirical specification that captures the firm's decision to adopt socially responsible practices. In particular, we assume that firm performance is a linear function of the firm's characteristics as well as CSR, and that the decision to adopt CSR depends on the firm's characteristics. ${ }^{4}$ Two inter-related methodological issues arise in a non-experimental causal analysis like the current one (see for reviews Blundell and Costas Dias, 2000; 2002). First, we do not observe the counterfactual. This means that we have information on firm performance of CSR adopters and non-adopters only, but there is no information on the counterfactual (i.e. CSR adopters' performance in the case of non-adoption and vice-versa). The second problem is that the decision to adopt CSR (i.e. the treatment assignment) may depend on firms' characteristics and thus it is non-random. In other words, the group of adopters can be systematically different from non-adopters. This,

3. We assume that the data generating process can be described by two relations. The first, Equation (1) below, is an extended production function which describes the linear relationship between the i-th firm's performance (i.e. yi) and the firm's characteristics (i.e. Xi) as well as CSR and a normally distributed idiosyncratic error term. Equation (2) is instead an index function that models CSR adoption as a function of firms' characteristics. Formally:

$\ln y_{i}=\beta_{0}+\beta_{1} \ln \left(X_{i}\right)+\beta_{2} C R S_{i}+\mu_{i}$

$C S R_{i}^{*}=\not X_{i}+\varepsilon_{i}$

In particular, CSR* is a latent variable representing the difference in utility between CSR adoption and non-adoption, where the difference is estimated by the term. Although we will not estimate Equations (1) and (2) in our empirical exercise, clarifying the specific characteristics of the data-generating process is of fundamental importance in order to adopt the right econometric techniques.

4. Referring to the notation employed in the previous footnote, the selection bias arises when the error terms of the production function (i.e. $\mu$ in Equation 1) and the CSR choice (i.e. $\varepsilon$ in Equation 2) are correlated. 
in turn, implies a causality issue in the specific form of a selection bias, in the case that some unobservable factors influence both firm performance and the choice of engaging in CSR ${ }^{5}$ The traditional methodologies employed to control for the selection bias have been the Instrumental Variables (IV) approach and the Heckman two-steps estimator (Heckman, 1979). However, both approaches present some drawbacks. The main challenge of the IV approach is finding suitable identifying instruments that are correlated with the selection variable (i.e. CSR) but not with the outcome (i.e. firm performance). Moreover, IV procedures imply that the coefficients of the control variables are similar for adopters and non-adopters, an assumption which is unlikely to be satisfied since their coefficient may differ (Jalan and Ravallion, 2003). The main problem with the Heckman-two steps method, instead, is that it relies on the restrictive assumption of normally distributed errors (Becerril and Abdulai, 2010).

In order to investigate the causal relationship between CSR and firm performance, we adopt the Propensity Score Matching (PSM) approach. Unlike the aforementioned parametric methods, PSM has the advantage of not imposing any specific requirements on the functional form specifying the relationship between outcomes and predictors of outcomes ${ }^{6}$. Moreover, this paper employs survey-data, hence the problem of measurement error may arise as well.

\subsection{Propensity Score Matching}

PSM entails forming matched sets of treated and untreated subjects who share a similar value of the propensity score (Rosembaum and Rubin, 1983a, 1985). Following Rosembaum and Rubin (1983), the propensity score is defined as the probability of treatment assignment

5. For a full derivation of the ATT, the interested reader can refer to Becerril and Abdulai (2010), p.1026. 
conditional on observed baseline covariates. Formally: $\mathrm{e}_{i}=\operatorname{Pr}\left(Z_{i}=1 \mid \mathrm{X}_{i}\right)$. The propensity score is a balancing score: conditional on the propensity score, the distribution of measured baseline covariates is similar between treated and untreated subjects. Thus, in a set of subjects all of whom have the same propensity score, the distribution of observed baseline covariates will be the same between the treated and untreated subjects. In particular, PSM summarizes the pre-treatment characteristics of each subject into a single index variable, and then uses the propensity score to match similar individuals (Rosenbaum and Rubin, 1983a). Hence, PSM makes it possible to estimate the Average Treatment Effect for the Treated (henceforth ATT) (Imbens, 2004). The ATT is the average effect of treatment on those subjects who ultimately received the treatment. Formally, the ATT can be written as: $E\left[Y_{i}(1)-Y_{i}(0) \mid \mathrm{Z}=1\right]{ }^{7}$

The crucial assumption that underlies propensity score analyses is that the assignment to the treatment has been properly modelled or, as Rosenbaum and Rubin (1983a) put it, that the treatment assignment is "strongly ignorable". In particular, Rosenbaum and Rubin (1983a) demonstrate that if treatment assignment is strongly ignorable, conditioning on the propensity score allows one to obtain unbiased estimates of the ATT. Two assumptions are needed for a strongly ignorable treatment effect. The first is the Conditional Independence Assumption (CIA). CIA implies that selection into the treatment group is based solely on observable characteristics (selection on observables). Thus there are no unmeasured confounders that can affect the probability of treatment assignment. The second condition states that every subject has a non-zero probability of receiving or non-receiving the treatment. This hypothesis is called the "common support" or "overlap condition" because the common support is the area where the balancing score has positive density for both treatment and control units (Caliendo and Kopeinig, 2005).

6. For a full derivation of the ATT, the interested reader can refer to Becerril and Abdulai (2010), p.1026. 
The main drawback of PSM is that the CIA may be non-satisfied. As rightly noted by Smith and Todd (2005), there may be systematic differences in the treatment assignment between treated and untreated because of unmeasured confounders. However, Jalan and Ravallion (2003) convincingly argue that the assumption of selection on observables is no more restrictive than assuming away problems of weak instruments, when the Heckman two-steps estimator or the IV approach are employed in cross-sectional data analysis. Thus, with these caveats in mind, we rely on PSM for our exercise.

\subsection{Calculation of the propensity score, matching algorithms and ATT interpretation}

In order to choose the covariates to be included in the calculation of the propensity score, we draw on the existing literature on firm performance (e.g. Raiser, Allan and Steves, 2008; Johnson, McMillan and Woodruff, 1999; Carlin, Schaffer and Seabright, 2004). Moreover, we take into account the trade-off between omitted factors and over-parameterisation. If, on the one hand, omitting important factors can increase the selection bias (Heckman et al., 1998), on the other hand, over-parameterized models reduce the likelihood of finding a common support (Bryon et al., 2002). Thus, in order to ensure that the common support condition is satisfied, we follow Dehejia and Wahba (2002) and Diprete and Gangl (2004) and we include only a limited number of covariates. In light of these considerations, we

calculate the propensity score by employing the level of inputs used (labour and capital) and some selected firms characteristics, such as ownership, export intensity, size and RnD.

Once the propensity score has been calculated, different matching techniques can be employed to build the artificial and non-observed counterfactual.

There are several matching methods available. Asymptotically, all matching algorithms should generate the same results, although there are trade-offs in terms of bias and efficiency 
involved with each algorithm (Caliendo and Kopeining, 2005). In this paper we compare estimates of three different types of matching: kernel matching, nearest neighbour matching, and radius matching.

The kernel matching method is one of the most commonly used matching approaches. In particular, it is a non-parametric matching estimator that uses weighted averages of all individuals in the control group to construct the counterfactual. The weight assigned to each control observation depends on how close it is, in terms of propensity score, to a treated individual (Caliendo and Kopeinig, 2008).

The second matching method employed here is the Radius Matching with Calliper. A common issue with PSM is that matching may be of poor quality if the distance between controls and treated observations is large. The calliper imposes a maximum propensity score distance requirement. Calliper is often used with radius matching so that the algorithm uses the nearest neighbour for all the comparison members within the calliper, but it allows for larger distances when good matches are not available (Caliendo and Kopeinig, 2008).

The last matching method is the Nearest Neighbour Matching, also known to be one of the most straightforward methods. Matching between control and treated firms is done on the basis of the closest propensity score. The k-nearest neighbour matching allows the use of $\mathrm{k}$ units in the control group as matching partners for a treated individual. In this paper we set $\mathrm{k}$ equal to 3 . Thus we use just the three nearest neighbours.

Having formed the matched sample, the treatment effect can be estimated. This paper identifies the ATT of social and environmentally-oriented policies on selected measures of firms' performance. In particular, if the outcome variable is continuous (e.g. firms' turnover), the treatment effect can be interpreted as the average effect of treatment on those subjects who ultimately received the treatment (i.e. the increase or decrease in firms' sales due to CSR adoption). If, instead, the outcome variable is dichotomous (e.g. engaging or not in $\mathrm{RnD}$ ), the 
effect of the treatment can be estimated as the difference between the proportion of subjects experiencing the event in each of the two groups (treated vs. untreated) in the matched sample. With binary outcomes, the effect of the treatment can also be described using the relative risk or the Number Needed to Treat (Rosenbaum and Rubin, 1983a). ${ }^{8}$

Finally, we point out that all the estimations reported here have been performed in STATA 12.0 using the software provided by Leuven and Sianesi (2004).

\section{Data and Descriptive Statistics}

\subsection{CSR adoption, range of activities and perceived impact}

The data employed in this paper are drawn from the World Bank Enterprise Surveys (WEBS). WEBS is a firm-level survey conducted by experts on behalf of the World Bank. The survey is answered by top mangers of mainly service and manufacturing companies, and it covers a wide range of topics including characteristics of managers, perception of institutional constraints, and some basic financial information. ${ }^{9}$ These surveys have been used to investigate firms' performances by many well-known scholars (e.g. Djankov et al, 2008 and Beck et al. 2005). However, to the best of our knowledge, no one has made use of the information on CSR. The data are available for domestic and foreign-owned firms in Argentina, Bolivia, Chile, Colombia, Ecuador and Mexico.

The 2006 round of WBES contains 10 questions on CSR which give information on the following: whether the firm has any CSR-related practice; how CSR affects the establishment; if the firm has any energy, recycling or water optimisation programme; if the firm has a community support group; if the firm receives pressure to be socially responsible; if the firm

\footnotetext{
6. The number needed to treat (NNT) is an epidemiological measure used to communicate the effectiveness of a health-care intervention, typically a treatment with medication.

${ }^{9}$ Further details are available from http://www.enterprisesurveys.org.
} 
has any explicit policy on hiring women or handicapped persons or supporting the balance between family and work.

The 10 questions allow exploring three different dimensions of CSR, i.e. the environmental, social and labour ones. The survey also contains information on firms' turnover, size, sector of activity, export intensity, ownership and Research and Development (RnD) activities. This section analyses CSR practices across the six countries analysed, as well as the characteristics of firms engaged in CSR.

Table 1 summarises the WBES questions related to CSR for the six countries analysed. The table contains the percentage of firms that responded positively to the questions reported in the first column. The results are grouped according to the three CSR dimensions analysed, i.e. Environmental CSR (4 questions in WBES survey); Community CSR (1 question), and Labour CSR (2 questions).

The first row of Table 1 shows that between $44.38 \%$ and $78.59 \%$ of the firms surveyed have some oral or written CSR policies, with Mexico being the country with the lowest share and Ecuador the highest.

In regard to environmental practices, the survey contains 4 different questions (i.e. on the adoption of energy or water optimisation, recycling, and water/air pollution control). In order to summarize the information on Environmental CSR, we have generated a dummy variable, "CSR Environment", that is equal to 1 if the establishment adopts at least of one these practices. The fifth row in Table 1 shows that the majority of the firms have some environment-related practices. The minimum value of "CSR Environment" is $67 \%$ in Argentina, and the maximum is $87 \%$ in Ecuador.

WBES 2006 provides one question on the adoption of community support programmes. Thus, we can investigate the prevalence of CSR in the social dimension. In all countries the frequency of community projects seems lower than that of environmental practices. Ecuador 
again has the highest share of firms adopting community programmes, with $55 \%$, while Mexico has the lowest share with 22.54\%.

The questions related to the labour dimension of CSR provide information on two aspects: first, whether firms have explicit policies on hiring women or handicapped persons; second, whether they have programmes supporting the balance between family and work. We have repeated the same exercise done for Environmental CSR and built a dummy variable called "CSR Labour". The tenth row of Table 1 shows that, in all countries, the prevalence of labour-related practices is even lower than the adoption of community programmes. In particular, Argentina has the lowest share of firms engaged in Labour CSR (14.29 \%) while Ecuador is again the best performing country $(37.2 \%)$.

Overall, the data show that, in all the Latin American countries surveyed, there is a high share of firms engaged in some type of CSR. This is in line with Visser's (2008), which documents a trend of increasing CSR for Latin American countries. However, our data show that there is large variation in terms of the prevalence of various types of CSR. Environmental practices are the most common, while social and labour practices are less frequent. This finding is in consistent with Baskin's (2006) analysis, which notes that emerging markets lag behind the OECD for business ethics and equal opportunities, but are roughly on a par for environmental reporting.

For what concerns the prevalence of CSR in the countries analysed, Ecuador is the country with the highest share of firms engaged in CSR, for all the CSR dimensions analysed. Perhaps surprisingly, richer countries, such as Chile, Mexico and Argentina, perform poorly in relative terms. For instance, Mexico has the lowest share of firms engaged in CSR, in particular as regards community support projects (22\%). Ecuador, Colombia and Bolivia outperform Argentina, Mexico and Chile in terms of the share of firms engaged in environmental and labour CSR. This points to a weak correlation between a country's level 
of development (i.e. GNI per capita) and firm behaviour. ${ }^{10}$ Existing research shows that the adoption of CSR is contingent on the industry (Bansal and Roth, 2000; Strike, Gao and Bansal, 2006), societal culture (Waldam et al., 2006), and institutions (Frynas, 2005; Amaeshiet al., 2006). For instance, Ite (2005) identifies corruption, poor governance, and the lack of accountability to be the main hindrances to adopting CSR practices in Nigeria. Hence, an in-depth comparative legal and institutional analysis can help in identifying the drivers of the observed cross-counties differences. Because such analysis falls outside the scope of this paper, future research can shed light on this aspect.

Finally, the last two rows of Table 1 highlight that external pressures to adopt CSR practices are extremely low in all countries. Only 5\% of Mexican firms receive pressure to be socially/environmentally responsible, while the share is around one quarter in both Ecuador and Bolivia (25\% and 23\% respectively). However, in all countries, the majority of the firms agree that CSR has a positive impact on competitiveness. As much as $87 \%$ of Mexican firms believe that being socially responsible has a positive effect on the firm's competitiveness.

Overall, the descriptive statistics presented in Table 1 show that most companies do engage in some CSR activities, although there is a higher share of firms that adopt environmental programmes rather than labour practices or community projects. However, WBES data allow identifying only the type of CSR activities but not firms' expenditures on CSR performance.

\section{**Insert table 1 here**}

\subsection{Simultaneous CSR practices}

7. According to World Bank World Development Indicators, the three richest countries among the ones sampled are Chile, Argentina and Mexico, which have a GNI per capita in current US dollars equal to 15,245, 14,680 and 9,818 , respectively. The poorest are Bolivia, Ecuador and Colombia, with a GNI per capita equal to 2,576, 5,425 and 7,763 dollars respectively. 
As Muller and Kolk (2008) note, it is important to assess not only the prevalence of the various CSR practices but also the extent to which companies engage in them simultaneously. Table 2 shows the share of firms engaged in more than one type of CSR. In particular, it shows the pair-wise correlation between CSR-Environment, which is taken as the reference category, and CSR-Labour as well as CSR-Social, one at a time. The data shows that firms tend to adopt one or more aspect of CSR simultaneously. So, for example, the majority of firms that have environmental programmes also have labour policies or community projects. For instance, in Argentina only $10 \%$ of firms that have a community project do not have any environmental programme, while $24.36 \%$ of firms that adopt some labour standards fail to engage in environmental practices. Similarly in Colombia $89.88 \%$ of firms with CSR-Labour also has CSR-Environment, while $91.36 \%$ of firms with CSR-Social also have CSREnvironment. This pattern holds for all the countries examined.

**Insert table 2 here**

\subsection{CSR adoption and firms' characteristics}

We now explore the characteristics of the firms that adopt some CSR practices. Table 3 reports the descriptions of all the variables employed in this paper, while Table 4 summarises, for each country analysed, relevant firms' characteristics for two groups of establishments: CSR adopters and non-adopters, where CSR adopters are defined as firms that adopt at least one of the social, environmental or labour practices (see subsection 4.1 for details). Table 4 also reports the difference between the two groups of firms and the significance of such discrepancy. In particular, to assess the difference in the mean for adopters and non-adopters, we use the t-test for continuous variables and proportion test for dummy variables (in both cases the null hypothesis is that there is no statistically significant difference between the two groups analysed). 
Table 4 shows the differences in both the performance indicators related to our hypothesis and other key firm characteristics. In regard to the performance indicators, the data show that, in most countries, firms engaged in CSR tend to have higher sales and sales per employee, and this difference although small is significant. Moreover, there is a significantly higher share of firms engaged in $\mathrm{RnD}$ in the CSR adopters group compared to the non-adopters. Also CSR firms have significantly higher proportions of $\mathrm{RnD}$ expenditure to third parties compared to their counterparts. However, the ratio of total $\mathrm{RnD}$ expenditure to sales is not significantly different in the two groups. Interestingly, we also observe systematic differences in firms' characteristics between two groups of firms, at least on average. Within the CSR group there is a higher percentage of foreign, larger and older firms. For instance, in Argentina $12 \%$ of CSR firms are foreign-owned against $2 \%$ of foreign firms. Ownership does not appear to be significantly different in Colombia, Ecuador and Bolivia. Export intensity is usually higher for CSR firms; again this characteristic is not significantly different for Bolivia and Colombia. In regard to firm's size, small firms are more likely not to engage in CSR. In line with this observation, CSR firms have greater capital and a larger number of employees (labour), and such differences are significant. The prevalence of social and environmental practices also varies across sectors. This is not surprising since the pressures on companies to take up CSR depend on the social and economic impact of the economic activities carried out by the firm. Our data show that CSR practices are more common in the food and chemical sector, less common in clothing and textiles. This difference may be partly due to the fact that both the chemical and food industry are likely to have a strong impact on the environment. One factor that possibly explains the higher adoption of CSR practices in the food sector is that bargaining power often rests with large foreign processors and retailers, with the consequence that suppliers in developing countries are at a disadvantage (Jones et al., 2005; Maloni and Brown, 2006). However, the prevalence of CSR across sectors is again likely to 
be linked to firms' characteristics. In our sample, firms operating in the chemical sector are mainly foreign-owned, and establishments in the food sector are mainly large firms. By contrast, clothing and textile firms are mainly small and domestic-owned.

Besides the analysis of CSR adopters and non-adopters, Table 5 presents the correlation between our CSR index and some of the key covariates of interest. In line with the previous discussion, the table shows that the adoption of socially responsible practices is positively correlated with firms' size and experience, although the correlation is small. Moreover, firms that export, innovate and operate in the food and chemical sectors are also associated with greater CSR.

It should now be clear that, because of the observed differences, it is not possible to attribute the better performance of CSR firms to the their engagement in philanthropic activities. As our descriptive analysis seems to suggest, it may be that more productive firms are more likely to engage in such activities because, for example, they have more resources available. Hence, we adopted PSM in order to take these issues into account and thus obtain a purer identifiable effect of firms' socially responsible behaviour on their performance.

\footnotetext{
**Insert table 3 here**

**Insert table 4 here ${ }^{* *}$

**Insert table 5 here ${ }^{* *}$
}

\section{Results}

The results of our PSM exercise are reported in Tables 6, 7 and 8. The first column of each table reports the country under analysis as well as the matching procedure employed (i.e. Kernel, three nearest neighbours, or Radius). The second column shows the ATT which summarises the effect of the treatment (i.e. CSR adoption) on the treated. The third column 
shows the value of the t-statistics associated with the ATT. ${ }^{8}$ The last two columns report the firms pertaining respectively to the groups of CSR adopters (i.e. Treated) and non-adopters (i.e. Control) in the matched sample.

Table 6 presents the results on Hypothesis 1 and Hypothesis 2, which are related respectively to the impact of CSR on firms' revenues and labour productivity.

According to our first hypothesis, CSR should have a positive impact on firms' turnover (Jones, 1995; McWilliams and Siegel 2010). Panel A shows the causal impact of CSR on firms' revenues, expressed in thousands of current US dollars, where the matching exercise has been based on firms' ownership, age, export intensity, RnD, capital and employment. Our results show that in Bolivia, Colombia and Ecuador the ATT is positive and significant. For instance, in 2006, in Bolivia, sales by CSR adopters were almost 2 million dollars higher than those by non-adopters, while in Ecuador the difference amounted to only 650 dollars. In Colombia the ATT is significant only with three nearest neighbours matching, in which case it is 1 million 277 thousand dollars. The ATT is negative but not significant for Argentina and Chile, while in Mexico it is positive but not significant. Hence there seems to be some support for Hypothesis 1, although there is great variation in terms of ATT across the countries analysed.

Panel B in Table 6 reports the effect of CSR on sales per employee, expressed in current US dollars. According to our second hypothesis we expect CSR to have a positive impact on labour productivity because it promotes business reputation and employee empowerment. Similarly to what is reported in panel A, we find that the ATT is positive and significant for Bolivia and Colombia. For the former country, this effect is estimated at between $\$ 19,308$ and $\$ 19,808$, while for the latter the ATT is around $\$ 20,107$ and $\$ 20,597$.

\footnotetext{
${ }^{8}$ It might be useful to recall the critical values associated with Student's T, in a two tails test: 1.645 for $10 \%$ significance; 1.96 for $5 \%$ and 2.576 for $1 \%$.
} 


\section{** Insert table 6 here**}

Table 7 analyses the impact of CSR on innovation, as defined by the presence of investments in $\mathrm{RnD}$, either within the establishment or through a third party. Because the outcome variable is a dichotomous one, the ATT should be interpreted as the difference between the proportion of firms that engage in $\mathrm{RnD}$ in each of the two groups (CSR vs. non-CSR firms) in the matched sample. According to our third hypothesis, we should expect CSR to have a positive impact on innovation. This is because social and environmental practices may promote innovation networks, which may be linked to sustainability-oriented and/or regulation-induced innovations. In this instance there seems to be less variability across countries. In particular, the share of firms that engage in $\mathrm{RnD}$ activities is always higher for adopters of CSR than it is for non-adopters. The effect is significant in Argentina, Bolivia, Colombia and Mexico. It is the highest for Colombia, at around 32\%-34\%, and the lowest for Bolivia, at around 20\%-23\%. In Chile and Ecuador the ATT is again positive although not significant.

\section{** Insert table 7 here**}

In Table 8, we explore the link between CSR product differentiation (i.e. RnD to sales ratio) as well as CSR and technological transfer (i.e. RnD through a third party to sales ratio).

Panel A in Table 8 shows the results of the matching exercise when the outcome variable is $\mathrm{RnD}$ to sales ratio. Because CSR features embedded in firm products can be conceived as new products and thus constitute a form of technological advancement, we can expect a positive impact of CSR on product differentiation. Our results confirm this prediction, as the effect of CSR on product differentiation is positive in all countries. However, the effect is only significant in Mexico, where the share of RnD to sales is about 3.5\% higher for CSR adopters. But we should note that the control group in all the matching exercises reported in Panel A of Table 8 is very small, and this is likely to have affected our results. 
Moving to Panel B, we analyse the impact of CSR activities on technological transfer. Interestingly, we find a positive and significant effect in Argentina and Bolivia. In the former country, the share of $\mathrm{RnD}$ to third party to sales is $0.2 \%$ higher in the adopters group, while for the latter country the effect is around $1.1 \%$. Our results thus show that CSR can boost technological transfer to developing countries, so that our fifth hypothesis seems to be supported. We should note that, in Colombia, Ecuador and Mexico, we fail to find any significant effect in both panel A and B. However, the control groups are very small and this is likely to have affected our results.

\section{** Insert table 8 here**}

We now summarise our results by country. In Argentina, CSR has a positive and significant impact on firms' innovativeness and technological transfer. In Bolivia, we find a positive effect on firms' turnover, labour productivity, innovativeness, as well as technological transfer. In Chile, we do not find any significant effect on any of the variables analysed. In Colombia, CSR has a positive and significant impact on both labour productivity and innovation activities. In Ecuador, CSR firms have significantly higher turnover but there is no discernible effect on innovation activities. In Mexico, we only find a significant effect on firms' innovativeness and product differentiation.

Overall, our empirical analysis provides support for the hypotheses formulated in Section two, but with great variability across countries. Interestingly, poorer countries, such as Bolivia and Colombia, display the highest numbers of links between CSR and the outcome variables analysed. Here we find scope for a sizeable effect of CSR on firms' innovativeness, turnover, as well as labour productivity. Moreover, the strongest relationship between conscious business operation and innovation is found in the two largest countries analysed: Mexico and Argentina. 
Thus, our matching exercise shows that firms that engage in environmental or community projects never underperform firms that do not adopt such practices. The advocates of CSR claim that responsible firms' behaviour, towards both shareholders and stakeholders, is essential to compete in the global market. Our results suggest that corporate goals, such as productivity, sales and innovation, are compatible with conscious operations.

\section{Diagnostic Tests}

We can conjecture that, in many instances, insignificant results are driven by the small samples created in the matching process. In order to assess whether the quality of the matching is poor, and therefore whether the results are biased, we conducted two common diagnostic tests in the context of PSM.

The first test is known as the balancing propensity (of matched firms, in this specific case). In particular, following Rosenbaum and Rubin (1985), we employed the t-test to assess the equality of the mean of each covariate between the treatment and comparison groups. This diagnostic test therefore enabled us to check whether the observations with the same propensity scores had the same distribution of observable covariates or, more technically, whether the propensity score was an adequate balancing score. The results reported in Tables A1-A3 (in the Appendix) show that, after matching, in 91\% of cases the covariates of the treated and untreated groups were similar, indicating that the quality of the matching was good. Thus, we are confident that our exercise ensured an adequate "like-for-like comparison".

The second diagnostic test is the propensity score histogram (of the treated and untreated firms, in this specific case) developed by Yang and Mallik (2010). This graph helps in assessing the quantity of matched and unmatched firms within a given number of intervals of 
the propensity score range. Thus, this diagnostic is useful for testing the common support hypothesis. Figures A1-E6 (in the Appendix) show that most of the observations in the treated group could find matched firms in the untreated group with a similar propensity score. Table A4 summarises the number of observations on and off support for each matching exercise and country. This robustness check shows that for what concerns sales, sales per employee and $\mathrm{RnD}$ (measured as a dummy variable), Ecuador has the highest share of offsupport observations, respectively $39 \%$ and $44 \%$. The results for total $\mathrm{RnD}$ to sales and $\mathrm{RnD}$ to third party show that both Ecuador and Colombia have high shares of off-support observations. For conciseness, we only report this check for the Kernel matching, but the use of other algorithms leads to similar results. It is not surprising that when we have a high share of off-support observations, the matching exercise yields insignificant results.

To sum up, the t-test of covariate balancing after matching and propensity score histogram analysis demonstrates that the quality of matching is efficient.

\section{Conclusions}

Attention to the social and environmental roles of firms is not new. However, in the past decade there has been renewed interest in such issues. In the context of globalisation, firms are increasingly expected to play a positive role in society and thus contribute to sustainable development (Kolk and Tolder, 2010; Lozano, 2011). The empirical evidence on the link between responsible behaviour and firms' performance shows mixed results. Moreover, existing research on CSR remains focused on developed economies, and there is scant evidence on the extent and the type of CSR practices adopted in emerging markets.

In this paper, we have employed the firm-level data collected by the 2006 World Bank Enterprise Surveys (WEBS) on Bolivia, Argentina, Chile, Colombia, Mexico and Ecuador, and we have adopted PSM techniques to assess the causal relationship between CSR and firm performance. In particular, in order to highlight the peculiarities of business dynamics in 
developing countries, as well as to overcome data limitations, we have formulated five distinct theoretical hypotheses on the CSR/performance link, and we have examined the causal effects of socially responsible practices on firm turnover, labour productivity, innovativeness, product differentiation, and technological transfer.

Overall, our results provide supportive evidence for the theoretical hypotheses that we have formulated. They thus suggest that corporate goals are compatible with conscious operations in developing countries. However, the results tend to vary across countries and an interesting pattern emerges from our analysis: the strongest relationship between conscious business operations and innovativeness is found in the two largest middle-income countries analysed, namely Mexico and Argentina. In poorer countries, such as Bolivia and Colombia, we find that CSR has a positive and significant impact on firms' turnover, labour productivity, as well as innovativeness. Finally, no effect is found in Chile, the most developed country in our sample.

We can speculate that the positive effects of CSR depend on the country's stage of industrialisation. In particular, our analysis suggests that the less industrialised the economy, the wider the scope of CSR as a development booster. This may be related to the lower costs associated with imitation rather than innovation, as well as to the greater efficiency of more recent vintages of capital. As countries industrialise and begin to close the technological gap with technologically advanced economies, CSR fosters innovative activities and, most probably, it directs such technological advancement towards high international standards. Finally, once the country has industrialised, the developmental advantages of backwardness related to CSR disappear, although CSR can still play a very important role, in particular as a strategic factor.

The relationship among conscious business operations, firms' performance, and the country's level of development has not been directly tested in this paper. However, this opens up an 
interesting line of research. Further, it would be of extreme importance to assess the role that national policies play in shaping the relationship between CSR and firm performance (see for instance: Sobczak and Coelho Martins, 2010; Midttun et al. 2006). Narrative evidence suggests that the extent to which Latin American governments have actively promoted CSR varies across countries and sectors. In the majority of the cases, only few industries, such as the extractive one, and big companies have been targeted. Last but not the least, more research is required on what is meant by CSR in developing countries and what is its most suitable categorization (McIntyre et al. 2015, Schmidheiny, 2006 and Moir 2001). As for this study, its policy implications are of great relevance. In particular, it seems advisable that firms in least developed economies adopt CSR practices. Consequently, governments in emerging countries as well as international organisations should provide meaningful incentives for CSR adoption.

\section{References}

Acutt, N., Medina-Ross, V., and O’Riordan, T. (2004) 'Perspectives on Corporate Social Responsibility in the Chemical Sector: A Comparative Analysis of the Mexican and South African Cases.' Natural Resources Forum, Vol. 28, No. 4, pp. 302-16.

Adeyeye, A. (2011) 'Universal standards in CSR: are we prepared?' Corporate Governance: The international journal of business in society. Vol. 11, No. 1, pp.107-119

Amini, C. and Dal Bianco, S. (2015). Corporate Social Responsibility and Development in LatinAmerica. in Development-Oriented Corporate Social Responsibility, Vol.2, Jamali, D., Karam, C. and Blowfield, M. (eds), Greenleaf, Saltaire.

Ashford, A., and Hall, R. (2011) 'The importance of regulation-induced innovation for sustainable development.' Sustainability, Vol. 3, pp.270-292. 
Bansal, P., and Roth, K. (2000) 'Why companies go green: a model of ecological responsiveness.' Academy of Management Journal, Vol. 43, No. 4, August, pp. 717-736.

Baskin, J. (2006) 'Corporate Responsibility in Emerging Markets.' Journal of Corporate Citizenship, Vol. 24, No.1, pp. 29-47.

Baumol, W. (1962) 'Business Behavior, Value and Growth.' The Economic Journal, Vol.72, No. 287, pp. 708-711.

Baumol W. (1986) 'Productivity growth, convergence and welfare: what the long run data show.' American Economic Review, Vol. 76, No.5, pp. 1072-1085.

Becerril, J. and Abdulai, A. (2010) 'The Impact of Improved Maize Varieties on Poverty in Mexico: A Propensity Score-Matching Approach.' World Development, Vol. 38, No.7, pp. $1024-1035$.

Beck, T.,Demirguc-Kunt, A and Levine, R. (2005) 'Law and Firms' Access to Finance.' American Law and Economics Review, Vol. 7, No.1, pp. 211-252.

Becchetti, L., R. Ciciretti and I. Hasan. (2007) 'Corporate Social Responsibility and Shareholder's Value: An Event Study Analysis.' Working Paper 2007-6, Federal Reserve Bank of Atlanta.

Berliner, D. and Prakash, A. (2014) 'The United Nations Global Compact: An Institutionalist Perspective' Journal of Business Ethics. Vol. 122, No.2, pp 217-223.

Bird, R., Momentè, F. and Reggiani, F. (2007) 'What Corporate Social Responsibility Activities are Valued by the Market?' Journal of Business Ethics, Vol. 76, No.2, pp. 189-206.

Blowfield, M. (2003) 'Ethical Supply Chains in the Cocoa, Coffee and Tea Industries.' Greener Management International, Vol. 43, No.3, pp. 15-24. 
Blowfield, M. (2004) 'Implementation Deficits of Ethical Trade Systems: Lessons from the Indonesia Cocoa and Timber Industries.' Journal of Corporate Citizenship, Vol. 13, No. 2, pp. 77-90.

Blowfield, M. (2005) 'Corporate Social Responsibility: reinventing the meaning of development?' International Affairs, Vol. 81, No. 3, pp. 515-524.

Blundell, R., \& Costa Dias, M. (2000) 'Evaluation methods for non- experimental data.' Fiscal Studies, Vol. 21, No.4, pp. 427-468.

Blundell, R. and Costa Dias, M. (2002) 'Alternative approaches to evaluation in empirical microeconomics.' Portuguese Economic Journal, Vol. 1, pp. 91-115

Bowman, E. H. and Haire, M. (1975) 'A Strategic Posture Toward Corporate Social Responsibility.' California Management Review, Vol. 18, No.2, pp. 49-58.

Bragdon, J.H. and J. Marlin. (1972) 'Is Pollution Profitable.' Risk Management, Vol. 19, No 4, pp. 9-18.

Brammer, S., Jackson, G. and Matten, D. (2012) 'Corporate Social Responsibility and institutional theory: new perspectives on private governance.' Socio-Economic Review, Vol.10, No.1, pp. 3-28.

Brodhag, C. (2013) 'Research universities, technology transfer, and job creation: What infrastructure, for what training?' Studies in Higher Education, Vol. 38, No.3, pp. 388-404.

Caliendo, M. and S. Kopeing. (2005) Some practical guidance for the implementation of propensity score matching. IZA Discussion Paper, no. 1588, Bonn, Germany.

Carlin W., Schaffer, M. and Seabright, P. (2004) 'A Minimum Rivalry: Evidence from Transition Economies on the importance of Competition for Innovation and Growth.' William Davidson Institute, working paper №. 670. 
Chen, C. and Shang, Y. (2009) 'Ambition Versus Conscience, Does Corporate Social Responsibility Pay off? The Application of Matching Methods.' Journal of Business Ethics, Vol. 88, No.1, pp. 133-153.

Cochran, P. L. and Wood, R.A.(1984) 'Corporate Social Responsibility and Financial Performance.' Academy of Management Journal, Vol. 27, No.1, pp. 42-56.

Cook, R.J. and Sackett, D.L. (1995) 'The number needed to treat: a clinically useful measure of treatment effect.' British Medical Journal, 310:452

DalBianco S. (2010) 'New Evidence on Classical and Technological Convergence in Manufacturing.' La Rivista Italiana degli Economisti, Vol. 15, No.2, pp. 305-336.

Dal Bianco S. (2016) 'Going Clubbing in the Eighties: Convergence in Manufacturing Sectors at a Glance.' Empirical Economics, Vol. 5, No.2, pp. 623-659.

Dasgupta, S., Laplante, B., Wang, H and Wheeler, D. (2002) 'Confronting the Environmental Kuznets Curve.' Journal of Economic Perspectives, Vol. 16, No.1, pp. 147-168.

Dehejia, H.R. and S. Wahba. (2002) 'Propensity score matching methods for nonexperimental causal studies.' Review of Economic Statistics, Vol. 84, No.1, pp. 151-61.

Djankov, S. , La Porta, L., Lopez-de-Silanes, F, Shleifer, A. (2008) 'The law and economics of self-dealing.' Journal of Financial Economics, Vol. 88, No.3, pp. 430-465.

Frynas, J. (2005) 'The false developmental promise of Corporate Social Responsibility: evidence from multinational oil companies.' International Affairs. Vol. 81, No. 3, pp. 581598.

Gao, Y. (2009) 'Corporate social performance in China: Evidence from large companies.' Journal of Business Ethics, Vol. 89, No.1 pp. 23-35. 
Griffith R. , Harrison R. and Van Reenen J. (2006) 'How Special Is the Special Relationship? Using the Impact of US R\&D Spillovers on UK. Firms as a Test of Technology Sourcing.' American Economic Review, Vol. 96, No.5, pp. 1859-1875.

Griliches, Z. (1979) 'Issues in assessing the contribution of research and development to productivity growth.' Bell Journal of Economics, Vol 10, No.1, pp. 92-116.

Grossman, G.M. and Krueger, A.B. (1995) 'Economic growth and the Environment.' The Quarterly Journal of Economics, Vol. 110, No.2, pp. 353-377.

Hansen, E. G., Grosse-Dunker, F. and Reichwald, R.(2009) 'Sustainability innovation cube - a framework to evaluate sustainability-oriented innovations.' International Journal of Innovation Management, Vol.13, No.4, pp. 683-713.

Heckman, J. (1979) 'Sample selection bias as a specification error.' Econometrica, Vol. 47, No.1, pp. 153-161.

Heckman, J., LaLonde, R., \& Smith, J. (1999). The economics and econometrics of active labor market programs. In O. Ashenfelter, \& D. Card (Eds.) Handbook of labor economics $1^{\text {st }}$ Ed. (Vol. 3, pp. 1865-2097). Elsevier, London.

Heckamn, J., Ichimura, H., Smith, J. and Todd, P. (1998) 'Characterising Selection Bias Using Experimental Data.' Econometrica, Vol. 66, No.5, pp. 1017-1098.

Imbens G.W. (2004) 'Nonparametric estimation of average treatment effects under exogeneity: A review.' The Review of Economics and Statistics, Vol. 86, No.1, pp. 4-29.

Japan, J. and Ravelling, M. (2003) 'Does piped water reduce diarrheal for children in rural India?' Journal of Econometrics, Vol. 112, No.1, pp. 153-173.

Jamal, D. (2008) 'Corporate Governance and Corporate Social Responsibility Synergies and Interrelationships.' Corporate Governance: An International Review, Vol.16, No. 5, pp. 443459. 
Jamali, D., Sidani, Y., \& El-Asmar, K. (2009) 'Changing managerial CSR orientations: A three country comparative analysis of Lebanon, Syria and Jordan.' Journal of Business Ethics Vol. 85, No.1, pp. 173-192.

Jensen, M. (1988) 'Takeovers: Their causes and consequences.' Journal of Economic Perspectives, Vol. 2, No.1, pp. 21-44.

McGuire, J. Chiu, JSY and Elbing, A.O. (1962) 'Executive Incomes, Sales and Profits.' The American Economic Review, Vol. 52, No.4, pp. 753-761.

Atle Midttun, A.Gautesen, K. and Gjølberg, M. (2006) 'The Political Economy of CSR in Western Europe.' Corporate Governance: The international journal of business in society, Vol. 6, No.4, pp.369-385.

Moire, L. (2001) 'What do we mean by Corporate Social Responsibility.' Corporate Governance: The international journal of business in society, Vol. 1, No. 2, pp.16-22.

Johnson S., McMillan, J. and Woodruff, C.. (1999) Contract Enforcement in Transition. CESifo Working Paper Series, Working paper №211, available at: http://www.cesifogroup.de/portal/page/portal/DocBase_Content/WP/WP-CESifo_Working_Papers/wp-cesifo1999/cesifo_wp211.pdf (accessed: 14.05.2016)

Kapelus, P. (2002) 'Mining, Corporate Social Responsibility and the Case of Rio Tinto, Richards Bay Minerals and the Mbonambi.' Journal of Business Ethics, Vol. 39, No (3), pp. 275-96.

Kaufman, A., Tiantubtim, E., Pussayapibul, N. and Davids, P. (2004) 'Implementing Voluntary Labour Standards and Codes of Conduct in the Thai Garment Industry.' Journal of Corporate Citizenship, Vol. 13, No. 2, pp. 91-9.

Lado, A. and Wilson, M. C. (1994) 'Human resource systems and sustained competitive advantages: A competency-based perspective.' Academy of Management Review, Vol. 19, No. 4, pp. 699-727. 
Lall, S. (2002) 'Social Capital and Industrial Transformation.' Quenn Elizabeh House Working Paper Series, QEHWPS84, available at:

http://www3.qeh.ox.ac.uk/pdf/qehwp/qehwps84.pdf (accessed: 01.05.2016)

Leuven, E., and B. Sianesi. (2003) 'PSMATCH2: Stata Module to Perform Full Mahalanobis and Propensity Score Matching, Common Support Graphing, and Covariate Imbalance Testing'. Available at: http://fmwww.bc.edu/repec/bocode/p/psmatch2.ado (accessed: $01.01 .2015)$

Lozano, J. (2011) 'What emerges when a market emerges?' Corporate Governance: The international journal of business in society, Vol. 11, No.4, pp.315 - 326.

Luken, R. and Stares, R. (2005) 'Small Business Responsibility in Developing Countries: A Threat or an Opportunity?' Business Strategy and the Environment , Vol. 14, No. 1, pp. 3853.

Lund-Thomsen, P. (2004) 'Towards a Critical Framework on Corporate Social and Environmental Responsibility in the South: The Case of Pakistan.' Development, Vol. 47, No.3, pp. 106-113.

Maloni, M. J. and Brown, M. E. (2006) 'Corporate social responsibility in the supply chain: an application in the food industry.' Journal of Business Ethics, Vol. 68, No. 1, pp. 35-52.

Margolis, J. D., \& Walsh, J. P. (2003) 'Misery loves companies: Whither social initiatives by business?' Administrative Science Quarterly, Vol. 48, pp. 268-305.

McIntyre, M.L., Murphy, S.A. and Tetrault Sirsly, C.A. (2015) 'Do firms seek social license to operate when stakeholders are poor? Evidence from Africa.' Corporate Governance, Vol. 15, No.3, pp.306 - 314

McWilliams, A. and Siegel, D. (2000) 'Corporate social responsibility and financial performance: correlation or misspecification?' Strategic Management Journal, Vol. 21, No. 5, pp. 525-623. 
McWilliams, A. and Siegel, D.S. (2001) 'Corporate Social Responsibility: a Theory of the Firm Perspective.' Academy of Management Review, Vol. 26, No. 1, pp.117-127.

McWilliams,A., DS, Siegel and Wright P.M. (2006) 'Corporate Social Responsibility: Strategic Implications. ‘ Journal Of Management Studies, Vol. 43, No.1, pp.1-18

McWilliams, A. and Siegel, D.S. (2010) 'Creating and capturing value: Strategic corporate social responsibility, resource-based theory, and sustainable competitive advantage. 'Journal of Management, Vol. 37, No.5, pp. 1480-1495

Moon, J. (2007) 'The contribution of corporate social responsibility to sustainable development.' Sustainable Development, Vol. 15, No.5, pp. 296-306.

Moore, J.F. (2005) 'Business Ecosystems and the View From the Firm.' Antitrust Bull, Vol.51, No.1, pp. 31-75.

Moratis, L. (2015) 'The credibility of corporate CSR claims: a taxonomy based on ISO 26000 and a research agenda.' Total Quality Management \& Business Excellence, available at: http://www.tandfonline.com/doi/abs/10.1080/14783363.2015.1050179?journalCode=ctqm20 (accessed: 05.01.2016)

Muller, A. and Kolk, A. (2009) 'CSR performance in emerging markets: Evidence from Mexico.' Journal of Business Ethics, Vol. 85, No.2, pp. 325-337.

Nelson R. - Phelps E. (1966) 'Investment in humans, technological diffusion and economic growth.' American Economic Review, Vol. 56, No. 2, pp. 69-75.

Newell and Muro, A. (2006) 'Corporate Social and Environmental Responsibility in Argentina: The Evolution of an Agenda.' Journal of Corporate Citizenship, Vol. 24, No. 1, pp. $49-68$.

Orlitzky, M., Rynes, F. L., \& Schmidt, S. L. (2003) 'Corporate social and financial performance: A meta-analysis.' Organization Studies, Vol. 24, No.2, pp. 103-441. 
Porter, M. E. and van der Linde, C. (1995) 'Green and Competitive. Ending the Stalemate.' Harvard Business Review, September-October, pp. 120-135

Porter, M. and van derLinde, C. (1995) 'Towards a new conception of environment competitiveness relationship.' Journal of Economic Perspectives, Vol. 9, No. 4, pp.97-118.

Raiser, M., R. Allan, and F. Steves. (2008) 'Trust in Transition: Cross Country and Firm Evidence.' Journal of Law, Economics, and Organization, Vol. 24, No. 2, pp. 407-433.

Rosenbaum P.R. and Rubin D.B. (1983(a)) 'The central role of the propensity score in observational studies for causal effects.' Biometrika. Vol, 70, No. 1, pp. 41-55.

Rosenbaum P.R., and Rubin D.B. (1983(b)) ‘Assessing sensitivity to an unobserved binary covariate in an observational study with binary outcome.' Journal of the Royal Statistical Society, Series B, Vol. 45, No.2, pp. 212-218.

Rosenbaum P.R., and Rubin D.B. (1985) 'Constructing a control group using multivariate matched sampling methods that incorporate the propensity score.' The American Statistician, Vol. 9, No.1, pp. 33-38.

Russo, A. and Perrini, F. (2010) 'Investigating Stakeholder Theory and Social Capital: CSR in Large Firms and SMEs.' Journal of Business Ethics, Vol. 91, No. 1, pp. 207-221.

Sanchez, P.E. and Benito-Hernandez, S. (2013) 'CSR Policies: Effects on Labour Productivity in Spanish Micro and Small Manufacturing Companies.' Journal of Business Ethics, Vol. 128, No.4, pp. 705-724.

Schmidheiny, S. (2006) 'A View of Corporate Citizenship in Latin America.' Journal of Corporate Citizenship, Vol. 21, No.3, pp. 21-4.

Sobczak, A. and Coelho Martins, L. (2010) 'The impact and interplay of national and global CSR discourses: insights from France and Brazil.' Corporate Governance: The international journal of business in society, Vol. 10, No. 4 , pp. 445-455

Strike, V. M., Gao, J. and Bansal, P. (2006) 'Being good while being bad: Social responsibility and the international diversification of US firms.' Journal of International Business Studies, Vol. 37, No. 6, pp. 850-862. 
Stuebs, M. \& Sun, L. (2010) 'Business reputation and labor efficiency, productivity, and cost.' Journal of Business Ethics, Vol. 96, No. 2, pp. 265-283.

Turban, D. B. and D. W. Greening. (1997) 'Corporate Social Performance and Organizational Attractiveness to Prospective Employees.' Academy of Management Journal, Vol. 40, No.1, pp. 658-672.

Yong, Yang \& Mallick, S. (2010) 'Export Premium, Self-selection and Learning-byExporting: Evidence from Chinese Matched Firms.' The World Economy, Vol. 33, No. 10, pp. 1218-1240.

Ullmann, A. (1985) 'Data in search of a theory: a critical examination of the relationship among social performance, social disclosure and economic performance of US firms.' Academy of Management Review, Vol.10, No. 1, pp. 540-557.

Vella, F. \&Verbeek, M. (1999) ‘ Estimating and interpreting models with endogenous treatment effects.' .Journal of Business \& Economic Statistics, Vol. 17, No.4, pp. 473-478.

Visser, W. (2008) Corporate social responsibility in developing countries. In A. Crane, A. McWilliams, D. Matten, J. Moon, \& D. Siegel (Eds.), The Oxford Handbook of Corporate Social Responsibility (pp. 473-479). Oxford University Press, Oxford.

Vivarta, V., and Canela, G. (2006) 'Corporate Social Responsibility in Brazil: The Role of the Press as Watchdog.' Journal of Corporate Citizenship, Vol. 21, No. 2, pp. 95-106.

Vives, A. (2006) 'Social and Environmental Responsibility in Small and Medium Enterprises in Latin America.' Journal of Corporate Citizenship, Vol, 21, No. 2, pp. 39-50.

Waddock, S. and Graves, S. (1997) 'The Corporate Social Performance - Financial Performance Link.' Strategic Management Journal, Vol. 18, No.4, pp. 303-319.

Welford, R. (2005) 'Corporate Social Responsibility in Europe, North America and Asia.' Journal of Corporate Citizenship, Vol. 17, No. 2, pp. 33-52. 
Weyzig, F. (2006) 'Local and Global Dimensions of Corporate Social Responsibility in Mexico.' Journal of Corporate Citizenship, Vol. 24, No.1, pp. 69-81.

Zhuang, C. and Wheale, P. (2004) 'Creating Sustainable Corporate Value: A Case Study of Stakeholder Relationship Management in China.' Business and Society Review, Vol. 109, No.4, pp. 507-47.

Table 1: CSR adoption, range of activities and perceived impact

\begin{tabular}{|c|c|c|c|c|c|c|}
\hline & Argentina & Bolivia & Chile & Colombia & Ecuador & Mexico \\
\hline \multicolumn{7}{|c|}{ CSR Adoption } \\
\hline $\begin{array}{l}\text { The firm has } \\
\text { written/oral CSR } \\
\text { policies }\end{array}$ & 65.83 & 77.84 & 75.12 & 63.69 & 78.59 & 44.38 \\
\hline Observations & 641 & 361 & 623 & 633 & 355 & 1105 \\
\hline \multicolumn{7}{|c|}{ Environmental CSR } \\
\hline $\begin{array}{l}\text { The firm has an energy } \\
\text { use optimization program }\end{array}$ & 39.07 & 47.53 & 47.32 & 45.81 & 63.16 & 56.94 \\
\hline $\begin{array}{l}\text { The firm has an water } \\
\text { use optimization program }\end{array}$ & 33.75 & 52.88 & 39.81 & 50.4 & 64.54 & 48.38 \\
\hline $\begin{array}{l}\text { The firm has recycling } \\
\text { program }\end{array}$ & 33.28 & 38.95 & 43.06 & 63.03 & 59.62 & 36.47 \\
\hline $\begin{array}{l}\text { Use any standardized } \\
\text { water and air pollution } \\
\text { control system? }\end{array}$ & 53.2 & 46.69 & 48.89 & 40.63 & 63.97 & 39.43 \\
\hline CSR Environment* & 67.45 & 77.26 & 73.23 & 79.78 & 87.26 & 70.15 \\
\hline \multicolumn{7}{|c|}{ Community CSR } \\
\hline $\begin{array}{l}\text { The firm has a community } \\
\text { support program }\end{array}$ & 46.39 & 53.95 & 45.37 & 39.65 & 55.52 & 22.54 \\
\hline \multicolumn{7}{|c|}{ Labour CSR } \\
\hline $\begin{array}{l}\text { Have explicit policy } \\
\text { about hiring women or } \\
\text { handicapped persons }\end{array}$ & 6.34 & 13.7 & 7.13 & 6.8 & 18.01 & 12.71 \\
\hline $\begin{array}{l}\text { Have programs supporting } \\
\text { balance between family } \\
\text { and work }\end{array}$ & 11.2 & 23.22 & 15.61 & 20.48 & 28.89 & 11.32 \\
\hline CSR Labour** & 14.29 & 29.32 & 18.82 & 24.13 & 37.22 & 20.49 \\
\hline \multicolumn{7}{|c|}{ External Pressures and Perceived impact } \\
\hline $\begin{array}{l}\text { Receive pressure to be } \\
\text { socially/environmentally } \\
\text { responsible }\end{array}$ & 13.34 & 23.16 & 18.08 & 11.85 & 25.14 & 5.7 \\
\hline $\begin{array}{l}\text { Being socially } \\
\text { responsible has a } \\
\text { positive effect on the } \\
\text { firm competitiveness }\end{array}$ & 59.95 & 78.21 & 67.9 & 81.33 & 81.72 & 86.34 \\
\hline
\end{tabular}

*CSR Environment takes value 1 if the firm engages in one of the environmental practices surveyed.

** CSR Labour takes value 1 if the firm has answered yes to one of the two questions on labour practices. 


\begin{tabular}{|c|c|c|c|c|c|c|c|c|}
\hline \multirow[b]{3}{*}{ CSR-Environment } & \multicolumn{4}{|c|}{ Argentina } & \multicolumn{4}{|c|}{ Bolivia } \\
\hline & \multicolumn{2}{|c|}{ CSR-Labour } & \multicolumn{2}{|c|}{ CSR-Social } & \multicolumn{2}{|c|}{ CSR-Labour } & \multicolumn{2}{|c|}{ CSR-Social } \\
\hline & 0 & 1 & 0 & 1 & 0 & 1 & 0 & 1 \\
\hline 0 & 142 & 57 & 4 & 6 & 45 & 22 & 12 & 4 \\
\hline \% & $45.81 \%$ & $24.36 \%$ & $13.33 \%$ & $10 \%$ & $33.58 \%$ & $17.89 \%$ & $35.29 \%$ & $5.56 \%$ \\
\hline 1 & 168 & 177 & 26 & 54 & 89 & 101 & 22 & 68 \\
\hline$\div$ & $54.19 \%$ & $75.64 \%$ & $86.67 \%$ & $90 \%$ & $66.42 \%$ & $82.11 \%$ & $64.71 \%$ & $94.44 \%$ \\
\hline Tot & 310 & 234 & 30 & 60 & 134 & 123 & 34 & 72 \\
\hline \multicolumn{9}{|l|}{ Observations } \\
\hline & \multicolumn{4}{|c|}{ Chile } & \multicolumn{4}{|c|}{ Colombia } \\
\hline & \multicolumn{2}{|c|}{ CSR-Labour } & \multicolumn{2}{|c|}{ CSR-Social } & \multicolumn{2}{|c|}{ CSR-Labour } & \multicolumn{2}{|c|}{ CSR-Social } \\
\hline CSR-Environment & 0 & 1 & 0 & 1 & 0 & 1 & 0 & 1 \\
\hline 0 & 112 & 40 & 7 & 9 & 92 & 17 & 9 & 7 \\
\hline$\%$ & $37.58 \%$ & $19.51 \%$ & $16.28 \%$ & $12 \%$ & $29.77 \%$ & $10.12 \%$ & $12.86 \%$ & $8.64 \%$ \\
\hline 1 & 186 & 165 & 36 & 66 & 217 & 151 & 61 & 74 \\
\hline$\div$ & $62.42 \%$ & $80.49 \%$ & $83.72 \%$ & $88 \%$ & 70.23 & $89.88 \%$ & 87.14 & $91.36 \%$ \\
\hline Tot & 298 & 205 & 43 & 75 & 309 & 168 & 70 & 81 \\
\hline \multicolumn{9}{|l|}{ Observations } \\
\hline & \multicolumn{4}{|c|}{ Ecuador } & \multicolumn{4}{|c|}{ Mexico } \\
\hline & \multicolumn{2}{|c|}{ CSR-Labour } & \multicolumn{2}{|c|}{ CSR-Social } & \multicolumn{2}{|c|}{ CSR-Labour } & \multicolumn{2}{|c|}{ CSR-Social } \\
\hline CSR-Environment & 0 & 1 & 0 & 1 & 0 & 1 & 0 & 1 \\
\hline 0 & 18 & 17 & 7 & 3 & 261 & 16 & 36 & 3 \\
\hline$\%$ & $14.88 \%$ & $16.19 \%$ & $17.95 \%$ & $3.16 \%$ & $38.33 \%$ & $9.58 \%$ & $25.35 \%$ & $3.90 \%$ \\
\hline 1 & 103 & 88 & 32 & 92 & 420 & 151 & 106 & 74 \\
\hline$\%$ & $85.12 \%$ & $83.81 \%$ & $82.05 \%$ & $96.84 \%$ & $61.67 \%$ & $90.42 \%$ & $74.65 \%$ & $96.10 \%$ \\
\hline Tot & 121 & 105 & 39 & 95 & 681 & 167 & 142 & 77 \\
\hline Observations & & & & & & & & \\
\hline
\end{tabular}

Notes: See Table 1 for the definitions of CSR-Environment and CSR-Labour. CSR-Social takes value 1 if the firm has a community support project.

Table 3: Variables' description

\begin{tabular}{|c|c|}
\hline Variable & Description \\
\hline Sales & Last complete fiscal year's total annual sales \\
\hline CSR & Dummy variable equal to 1 if the firm engages in AT LEAST one CSR practice \\
\hline Foreign & Dummy variable equal to 1 if the foreign ownership is greater than $10 \%$ \\
\hline Export & \% of sales exported directly and indirectly \\
\hline $\mathrm{RnD}$ & $\begin{array}{l}\text { Dummy variable equal to } 1 \text { if the firm invested in RnD within the } \\
\text { establishment or through a third party }\end{array}$ \\
\hline RnDSales & Share of total RnD to sales \\
\hline RnDExternal & Share of RnD through a third party to sales \\
\hline Age & firm age in 2006 \\
\hline Size1 & Dummy variable equal to 1 for small size firms (5-19 employees) \\
\hline Size2 & Dummy variable equal to 1 for medium size firms (20-99 employees) \\
\hline Size3 & Dummy variable equal to 1 for large size firms (>99 employees) \\
\hline Female owners & Dummy variable equal to 1 if any of the principal owners are female \\
\hline
\end{tabular}




\begin{tabular}{|l|l|}
$\begin{array}{l}\text { Skilled/Unskilled } \\
\text { L }\end{array}$ & Ratio of skilled to unskilled workers \\
\hline Capital & Net book Value of machinery, vehicles and equipment \\
\hline Labour & Number of full-time permanent workers at the end of last fiscal year \\
\hline Industry dummies & $\begin{array}{l}\text { Equal to } 1 \text { if the firm pertains to a certain industry (i.e. Food, Clothes, } \\
\text { Textiles, Machinery, Chemicals and other Manufacturing) }\end{array}$ \\
\hline CSR & $\begin{array}{l}\text { Dummy variable equal to } 1 \text { if the firm engages at least in one CSR activity } \\
\text { (i.e. Environmental, labour or social). }\end{array}$ \\
\hline CSR Environment & $\begin{array}{l}\text { Dummy variable equal to } 1 \text { if the firm engages in one of the environmental } \\
\text { practices surveyed. }\end{array}$ \\
\hline CSR Labour & $\begin{array}{l}\text { Dummy variable equal to } 1 \text { if the firm has answered yes to one of the two } \\
\text { questions on labour practices. }\end{array}$ \\
\hline CSR Social & Dummy variable equal to 1 if the firm has a community support project. \\
\hline
\end{tabular}

Table 4: Firms' characteristics: CSR adopters and non-adopters

\begin{tabular}{|c|c|c|c|c|c|c|c|c|c|}
\hline & \multicolumn{3}{|c|}{ Argentina } & \multicolumn{3}{|c|}{ Bolivia } & \multicolumn{3}{|c|}{ Chile } \\
\hline & CSR & $\begin{array}{l}\text { No } \\
\text { CSR }\end{array}$ & $\begin{array}{c}\text { Proportio } \\
\text { n/t-test } \\
\text { (p-value) }\end{array}$ & CSR & $\begin{array}{l}\text { No } \\
\text { CSR }\end{array}$ & $\begin{array}{c}\text { Proportio } \\
\text { n/t-test } \\
\text { (p-value) }\end{array}$ & CSR & $\begin{array}{l}\text { No } \\
\text { CSR }\end{array}$ & $\begin{array}{c}\text { Proportio } \\
\text { n/t-test } \\
\text { (p-value) }\end{array}$ \\
\hline $\begin{array}{l}\text { Sales per } \\
\text { employee }\end{array}$ & 11.65 & 11.46 & .0479 & 11.26 & $\begin{array}{c}10.8 \\
6\end{array}$ & .096 & 16.88 & 16.62 & .072 \\
\hline Sales & $\begin{array}{c}15551 \\
777\end{array}$ & $\begin{array}{c}12362 \\
29\end{array}$ & .022 & $\begin{array}{c}23840 \\
38\end{array}$ & $\begin{array}{c}2184 \\
12\end{array}$ & .0821 & $\begin{array}{c}1178633 \\
728\end{array}$ & $\begin{array}{c}14426 \\
476\end{array}$ & .647 \\
\hline Foreign & .123 & .028 & .001 & .102 & .088 & .776 & .091 & .017 & .008 \\
\hline Export & 14.6 & 6.68 & .002 & 11.65 & $\begin{array}{c}16.8 \\
2\end{array}$ & .239 & 10.39 & 3.919 & .005 \\
\hline $\mathrm{RnD}$ & .561 & .288 & .000 & .476 & .177 & .002 & .365 & .205 & .001 \\
\hline RnDSales & .0074 & $\begin{array}{c}.0020 \\
9\end{array}$ & 0.086 & $\begin{array}{c}.0137 \\
3\end{array}$ & $\begin{array}{l}.006 \\
38\end{array}$ & 0.537 & .0046 & .0058 & .719 \\
\hline RnDExternal & .0288 & $\begin{array}{c}.0205 \\
0\end{array}$ & 0.086 & $\begin{array}{c}.0365 \\
3\end{array}$ & $\begin{array}{l}.079 \\
49\end{array}$ & 0.055 & .3561 & .0247 & .710 \\
\hline Age & 33.74 & 26.02 & .001 & 22.61 & $\begin{array}{c}15.8 \\
6\end{array}$ & .010 & 30.55 & 25.9 & .036 \\
\hline Size1 & .361 & .605 & .000 & .496 & .6 & .195 & .257 & .482 & .000 \\
\hline Size2 & .416 & .336 & .279 & .347 & .333 & .848 & .465 & .428 & .474 \\
\hline Size3 & .222 & .028 & .000 & .155 & .066 & .113 & .276 & .089 & .000 \\
\hline Capital & $\begin{array}{c}58605 \\
64\end{array}$ & $\begin{array}{c}20739 \\
8\end{array}$ & .079 & $\begin{array}{c}19971 \\
00\end{array}$ & $\begin{array}{c}2848 \\
29\end{array}$ & .342 & 8146716 & $\begin{array}{c}32058 \\
8\end{array}$ & .272 \\
\hline Labor & 192 & 26.3 & .0320 & 54.51 & $\begin{array}{c}22.6 \\
4\end{array}$ & .071 & 136.33 & 37.95 & .013 \\
\hline $\begin{array}{l}\text { Female } \\
\text { owners }\end{array}$ & .341 & .366 & .586 & .436 & .511 & .347 & .375 & .432 & .276 \\
\hline $\begin{array}{l}\text { Skilled/unsk } \\
\text { illed L }\end{array}$ & 2.46 & 2.12 & .74 & 1.57 & 1.80 & .616 & 1.40 & 2.11 & .032 \\
\hline Food & .303 & .077 & .000 & .354 & .2 & .040 & .261 & .187 & .100 \\
\hline Clothes & .138 & .33 & .000 & .282 & .666 & .000 & .099 & .169 & .031 \\
\hline Textile & .174 & .204 & .4182 & .180 & .022 & .006 & .059 & .160 & .003 \\
\hline
\end{tabular}




\begin{tabular}{|c|c|c|c|c|c|c|c|c|c|}
\hline Machinery & .178 & .225 & .2084 & .059 & .022 & .308 & .055 & .035 & .395 \\
\hline Chemical & .109 & .007 & .0001 & .124 & .088 & .494 & .129 & .053 & .022 \\
\hline \multirow{3}{*}{$\begin{array}{l}\text { Other } \\
\text { Manufacturin } \\
g\end{array}$} & .0952 & .1549 & .043 & $\mathrm{n} / \mathrm{a}$ & $\mathrm{n} / \mathrm{a}$ & $\mathrm{n} / \mathrm{a}$ & $\mathrm{n} / \mathrm{a}$ & $\mathrm{n} / \mathrm{a}$ & $\mathrm{n} / \mathrm{a}$ \\
\hline & \multicolumn{3}{|c|}{ Colombia } & \multicolumn{3}{|c|}{ Ecuador } & \multicolumn{3}{|c|}{ Mexico } \\
\hline & CSR & $\begin{array}{l}\text { No } \\
\text { CSR }\end{array}$ & $\begin{array}{c}\text { Proportio } \\
\text { n/t-test } \\
\text { (p-value) }\end{array}$ & CSR & $\begin{array}{l}\text { No } \\
\text { CSR }\end{array}$ & $\begin{array}{c}\text { Proportio } \\
\text { n/t-test } \\
\text { (p-value) }\end{array}$ & CSR & $\begin{array}{l}\text { No } \\
\text { CSR }\end{array}$ & $\begin{array}{c}\text { Proportio } \\
\text { n/t-test } \\
\text { (p-value) }\end{array}$ \\
\hline $\begin{array}{l}\text { Sales per } \\
\text { employee }\end{array}$ & 17.57 & 17.24 & .003 & 10.28 & 9.34 & .0026 & 12.38 & 12.04 & .001 \\
\hline Sales & $\begin{array}{c}36126 \\
62\end{array}$ & $\begin{array}{c}42775 \\
9\end{array}$ & .087 & 226 & 16 & .092 & $\begin{array}{c}3128658 \\
0\end{array}$ & $\begin{array}{c}77652 \\
8\end{array}$ & .052 \\
\hline Foreign & .0241 & .010 & .425 & .125 & .166 & .608 & .104 & .026 & .001 \\
\hline Export & 9.24 & 8.68 & .806 & 8.57 & 1.11 & .077 & 8.42 & .498 & .000 \\
\hline $\mathrm{RnD}$ & .4935 & .1648 & .000 & .504 & .222 & .019 & .268 & .022 & .000 \\
\hline RnDSales & .0075 & $\begin{array}{c}.0005 \\
7\end{array}$ & 0.308 & .0061 & $\begin{array}{c}.000 \\
1\end{array}$ & 0.695 & .006 & .001 & .709 \\
\hline RnDExternal & .0286 & $\begin{array}{c}.0350 \\
3\end{array}$ & 0.655 & .0288 & $\begin{array}{c}.020 \\
7\end{array}$ & 0.736 & .0424 & .007 & .689 \\
\hline Age & 19.13 & 11.38 & .000 & 24.39 & $\begin{array}{c}17.9 \\
4\end{array}$ & .069 & 20.8 & 15.5 & .000 \\
\hline Size1 & .491 & .663 & .002 & .402 & .666 & .026 & .408 & .716 & .000 \\
\hline Size2 & .402 & .293 & .047 & .277 & .341 & .579 & .326 & .237 & .006 \\
\hline Size3 & .105 & .043 & .061 & .256 & .055 & .053 & .264 & .045 & .000 \\
\hline Capital & $\begin{array}{c}17195 \\
08\end{array}$ & $\begin{array}{c}21006 \\
8\end{array}$ & .279 & 61 & 11 & .320 & 2559811 & $\begin{array}{l}69120 \\
0\end{array}$ & .041 \\
\hline Labor & 69.48 & 18.47 & .057 & 80.75 & $\begin{array}{c}20.9 \\
4\end{array}$ & .126 & 125 & 23 & .000 \\
\hline $\begin{array}{l}\text { Female } \\
\text { owners }\end{array}$ & .532 & .510 & .824 & .342 & .277 & .573 & .248 & .235 & .663 \\
\hline $\begin{array}{l}\text { Skilled/unsk } \\
\text { illed L }\end{array}$ & 1.35 & 1.20 & .700 & 1.69 & 1.19 & .555 & 442 & 103 & .056 \\
\hline Food & .257 & .163 & .050 & .294 & .222 & .510 & .135 & .145 & .689 \\
\hline Clothes & .256 & .358 & .040 & .072 & .055 & .781 & .120 & .210 & .003 \\
\hline Textile & .207 & .358 & .001 & .064 & .055 & .884 & .135 & .157 & .338 \\
\hline Machinery & .276 & .119 & .001 & .005 & 0 & .745 & .230 & .149 & .005 \\
\hline Chemical & .001 & 0 & .679 & .274 & .111 & .127 & .180 & .065 & .000 \\
\hline $\begin{array}{l}\text { Other } \\
\text { Manufacturin } \\
g\end{array}$ & $\mathrm{n} / \mathrm{a}$ & $\mathrm{n} / \mathrm{a}$ & $\mathrm{n} / \mathrm{a}$ & .5 & .265 & .030 & $\mathrm{n} / \mathrm{a}$ & $\mathrm{n} / \mathrm{a}$ & $\mathrm{n} / \mathrm{a}$ \\
\hline
\end{tabular}

Table 5: Correlation Between CSR and Firms Characteristics

\begin{tabular}{lccccc}
\hline CSR & Argentina & Bolivia & Chile & Colombia & Equador \\
\hline Sales per employee & 0.0936 & 0.0928 & 0.0197 & 0.0592 & 0.0848 \\
Sales & 0.0911 & 0.1659 & 0.0705 & 0.1087
\end{tabular}




\begin{tabular}{|c|c|c|c|c|c|}
\hline Foreign & 0.1334 & 0.0436 & 0.1102 & 0.0373 & 0.0061 \\
\hline Export & 0.1502 & -0.066 & 0.1191 & 0.0015 & 0.0931 \\
\hline RnD & 0.2316 & 0.1531 & 0.1375 & 0.2389 & 0.1584 \\
\hline Age & 0.1258 & 0.1118 & 0.077 & 0.1658 & 0.0915 \\
\hline Size1 & -0.2061 & -0.0896 & -0.1732 & -0.1161 & -0.1464 \\
\hline Size2 & 0.0393 & 0.0115 & 0.0051 & 0.0758 & 0.0565 \\
\hline Size3 & 0.2142 & 0.112 & 0.1784 & 0.0717 & 0.1054 \\
\hline Skilled/unskilled L & 0.0182 & -0.0851 & -0.1073 & 0.0297 & 0.0105 \\
\hline Capital & 0.2891 & 0.0979 & 0.1681 & 0.1057 & 0.1386 \\
\hline Labor & 0.0862 & 0.1135 & 0.1055 & 0.0786 & 0.0912 \\
\hline Food & 0.2132 & 0.1451 & 0.0799 & 0.0808 & 0.0546 \\
\hline Clothes & -0.1976 & -0.3234 & -0.1116 & -0.0767 & -0.0084 \\
\hline Chemical & 0.1533 & 0.1672 & 0.0987 & 0.1288 & 0.0901 \\
\hline Machinery & -0.0513 & 0.0698 & 0.0395 & . & 0.0204 \\
\hline Other Manufacturing & -0.0736 & 0.0193 & -0.0148 & . & -0.075 \\
\hline
\end{tabular}

Table 6 PSM: CSR, Sales Revenue and Sales per Employees

Panel A: CSR \& Sales Revenue

Panel B: CSR \&Sales per employees

\begin{tabular}{|c|c|c|c|c|c|c|c|c|}
\hline $\begin{array}{l}\text { Matching } \\
\text { Estimator }\end{array}$ & $\mathrm{ATT}$ & $\begin{array}{c}\text { t- } \\
\text { ratio } \\
\text { ATT }\end{array}$ & Treated & Control & ATT & $\begin{array}{c}\text { t-ratio } \\
\text { ATT }\end{array}$ & Treated & Control \\
\hline \multicolumn{9}{|l|}{ Argentina } \\
\hline Kernel & -415.65 & -0.64 & 313 & 75 & -467.45 & -0.08 & 313 & 75 \\
\hline $\begin{array}{l}3 \text { Nearest } \\
\text { Neighbours }\end{array}$ & -575.30 & -0.84 & 313 & 75 & -342.77 & -0.06 & 313 & 75 \\
\hline Radius & -331.92 & -0.54 & 313 & 75 & -9.50 & -0.00 & 313 & 75 \\
\hline \multicolumn{9}{|l|}{ Bolivia } \\
\hline Kernel & 1764.08 & 2.43 & 199 & 27 & 19808.16 & 3.60 & 199 & 27 \\
\hline $\begin{array}{l}3 \text { Nearest } \\
\text { Neighbours }\end{array}$ & 1706.84 & 2.35 & 199 & 27 & 19691.11 & 3.57 & 199 & 27 \\
\hline Radius & 1783.06 & 2.46 & 199 & 27 & 19308.91 & 3.58 & 199 & 27 \\
\hline \multicolumn{9}{|l|}{ Chile } \\
\hline Kernel & -17390.56 & -0.70 & 335 & 59 & -665048.08 & -0.75 & 335 & 59 \\
\hline $\begin{array}{l}3 \text { Nearest } \\
\text { Neighbours }\end{array}$ & -34575.47 & -1.25 & 335 & 59 & -1276064.3 & -1.29 & 335 & 59 \\
\hline Radius & -18786.60 & -0.8 & 335 & 59 & -722818.44 & -0.86 & 335 & 59 \\
\hline \multicolumn{9}{|l|}{ Colombia } \\
\hline Kernel & 860.85 & 1.02 & 182 & 17 & 20196.92 & 2.18 & 182 & 17 \\
\hline $\begin{array}{l}3 \text { Nearest } \\
\text { Neighbours }\end{array}$ & 1277.56 & 2.03 & 182 & 17 & 20487.94 & 2.49 & 182 & 17 \\
\hline Radius & 1354.09 & 1.80 & 182 & 17 & 20597.08 & 2.34 & 182 & 17 \\
\hline \multicolumn{9}{|l|}{ Ecuador } \\
\hline Kernel & 0.657 & 2.03 & 230 & 10 & 8.37 & 1.46 & 230 & 10 \\
\hline 3 Nearest & 0.635 & 1.95 & 230 & 10 & 8.28 & 1.40 & 230 & 10 \\
\hline
\end{tabular}


Neighbours

\begin{tabular}{|c|c|c|c|c|c|c|c|c|}
\hline Radius & 0.673 & 2.08 & 230 & 10 & 8.03 & 1.45 & 230 & 10 \\
\hline Mexico & & & & & & & & \\
\hline Kernel & 689.97 & 1.49 & 536 & 187 & 11130.93 & 1.34 & 536 & 187 \\
\hline $\begin{array}{l}3 \text { Nearest } \\
\text { Neighbours }\end{array}$ & 740.72 & 1.56 & 536 & 187 & 12110.10 & 1.4 & 536 & 187 \\
\hline Radius & 700.67 & 1.54 & 536 & 187 & 11580.43 & 1.45 & 536 & 187 \\
\hline
\end{tabular}

In panel A the outcome variable is 2006 US dollar in thousands. Matching based on ownership, age, export intensity, RnD, capital and employment. In Panel B the outcome variable is sales per employees in 2006 US dollar. Matching is based on ownership, age, export intensity, RnD, capital and employment.

Table 6 PSM: CSR, Sales Revenue and Sales per Employees

Panel A: CSR \& Sales Revenue

Panel B: CSR \&Sales per employees

\begin{tabular}{|c|c|c|c|c|c|c|c|c|}
\hline $\begin{array}{l}\text { Matching } \\
\text { Estimator }\end{array}$ & $\mathrm{ATT}$ & $\begin{array}{c}\text { t- } \\
\text { ratio } \\
\text { ATT }\end{array}$ & Treated & Control & $\mathrm{ATT}$ & $\begin{array}{c}\text { t-ratio } \\
\mathrm{ATT}\end{array}$ & Treated & Control \\
\hline \multicolumn{9}{|l|}{ Argentina } \\
\hline Kernel & -415.65 & -0.64 & 313 & 75 & -467.45 & -0.08 & 313 & 75 \\
\hline $\begin{array}{l}3 \text { Nearest } \\
\text { Neighbours }\end{array}$ & -575.30 & -0.84 & 313 & 75 & -342.77 & -0.06 & 313 & 75 \\
\hline Radius & -331.92 & -0.54 & 313 & 75 & -9.50 & -0.00 & 313 & 75 \\
\hline \multicolumn{9}{|l|}{ Bolivia } \\
\hline Kernel & 1764.08 & 2.43 & 199 & 27 & 19808.16 & 3.60 & 199 & 27 \\
\hline $\begin{array}{l}3 \text { Nearest } \\
\text { Neighbours }\end{array}$ & 1706.84 & 2.35 & 199 & 27 & 19691.11 & 3.57 & 199 & 27 \\
\hline Radius & 1783.06 & 2.46 & 199 & 27 & 19308.91 & 3.58 & 199 & 27 \\
\hline \multicolumn{9}{|l|}{ Chile } \\
\hline Kernel & -17390.56 & -0.70 & 335 & 59 & -665048.08 & -0.75 & 335 & 59 \\
\hline $\begin{array}{l}3 \text { Nearest } \\
\text { Neighbours }\end{array}$ & -34575.47 & -1.25 & 335 & 59 & -1276064.3 & -1.29 & 335 & 59 \\
\hline Radius & -18786.60 & -0.8 & 335 & 59 & -722818.44 & -0.86 & 335 & 59 \\
\hline \multicolumn{9}{|l|}{ Colombia } \\
\hline Kernel & 860.85 & 1.02 & 182 & 17 & 20196.92 & 2.18 & 182 & 17 \\
\hline $\begin{array}{l}3 \text { Nearest } \\
\text { Neighbours }\end{array}$ & 1277.56 & 2.03 & 182 & 17 & 20487.94 & 2.49 & 182 & 17 \\
\hline Radius & 1354.09 & 1.80 & 182 & 17 & 20597.08 & 2.34 & 182 & 17 \\
\hline \multicolumn{9}{|l|}{ Ecuador } \\
\hline Kernel & 0.657 & 2.03 & 230 & 10 & 8.37 & 1.46 & 230 & 10 \\
\hline $\begin{array}{l}3 \text { Nearest } \\
\text { Neighbours }\end{array}$ & 0.635 & 1.95 & 230 & 10 & 8.28 & 1.40 & 230 & 10 \\
\hline Radius & 0.673 & 2.08 & 230 & 10 & 8.03 & 1.45 & 230 & 10 \\
\hline \multicolumn{9}{|l|}{ Mexico } \\
\hline Kernel & 689.97 & 1.49 & 536 & 187 & 11130.93 & 1.34 & 536 & 187 \\
\hline $\begin{array}{l}3 \text { Nearest } \\
\text { Neighbours }\end{array}$ & 740.72 & 1.56 & 536 & 187 & 12110.10 & 1.4 & 536 & 187 \\
\hline
\end{tabular}


In panel A the outcome variable is 2006 US dollar in thousands. Matching based on ownership, age, export intensity, RnD, capital and employment. In Panel B the outcome variable is sales per employees in 2006 US dollar. Matching is based on ownership, age, export intensity, RnD, capital and employment.

Table 7 PSM: CSR and RnD

\begin{tabular}{|c|c|c|c|c|}
\hline $\begin{array}{l}\text { Matching } \\
\text { Estimator }\end{array}$ & $\mathrm{ATT}$ & $\begin{array}{c}\text { t-ratio } \\
\mathrm{ATT}\end{array}$ & Treated & Control \\
\hline \multicolumn{5}{|l|}{ Argentina } \\
\hline Kernel & .2220 & 3.22 & 315 & 76 \\
\hline $\begin{array}{l}3 \text { Nearest } \\
\text { Neighbours }\end{array}$ & .2585 & 3.29 & 315 & 76 \\
\hline Radius & .2202 & 3.35 & 315 & 76 \\
\hline \multicolumn{5}{|l|}{ Bolivia } \\
\hline Kernel & .2030 & 2.39 & 202 & 32 \\
\hline $\begin{array}{l}3 \text { Nearest } \\
\text { Neighbours }\end{array}$ & .2362 & 2.58 & 202 & 32 \\
\hline Radius & .2070 & 2.5 & 202 & 32 \\
\hline \multicolumn{5}{|l|}{ Chile } \\
\hline Kernel & .0040 & 0.06 & 339 & 60 \\
\hline $\begin{array}{l}3 \text { Nearest } \\
\text { Neighbours }\end{array}$ & .0208 & 0.28 & 339 & 60 \\
\hline Radius & .0424 & 0.66 & 339 & 60 \\
\hline \multicolumn{5}{|l|}{ Colombia } \\
\hline Kernel & 3417 & 3.61 & 182 & 17 \\
\hline $\begin{array}{l}3 \text { Nearest } \\
\text { Neighbours }\end{array}$ & .3285 & 3.21 & 182 & 17 \\
\hline Radius & .3379 & 3.61 & 182 & 17 \\
\hline \multicolumn{5}{|l|}{ Ecuador } \\
\hline Kernel & .20489 & 1.55 & 232 & 11 \\
\hline $\begin{array}{l}3 \text { Nearest } \\
\text { Neighbours }\end{array}$ & .1827 & 1.32 & 232 & 11 \\
\hline Radius & .22947 & 1.77 & 232 & 11 \\
\hline \multicolumn{5}{|l|}{ Mexico } \\
\hline Kernel & .2309 & 9.47 & 548 & 191 \\
\hline $\begin{array}{l}3 \text { Nearest } \\
\text { Neighbours }\end{array}$ & .2270 & 8.80 & 548 & 191 \\
\hline Radius & .2319 & 9.71 & 548 & 191 \\
\hline
\end{tabular}

Table 8 PSM: CSR and Total RnD to sales ratio and RnD to Third party to sales ratio. 


\begin{tabular}{|c|c|c|c|c|c|c|c|}
\hline $\begin{array}{l}\text { Matching } \\
\text { Estimator }\end{array}$ & $\mathrm{ATT}$ & $\begin{array}{c}\text { t- } \\
\text { ratio } \\
\text { ATT }\end{array}$ & Treated & Control & $\mathrm{ATT}$ & $\begin{array}{c}\text { t-ratio } \\
\mathrm{ATT}\end{array}$ & Treated \\
\hline
\end{tabular}

\begin{tabular}{|c|c|c|c|c|c|c|c|c|}
\hline \multicolumn{9}{|l|}{ Argentina } \\
\hline Kernel & .03153 & 1.36 & 151 & 19 & .00281 & 2.73 & 160 & 20 \\
\hline $\begin{array}{l}3 \text { Nearest } \\
\text { Neighbours }\end{array}$ & .03153 & 1.22 & 151 & 19 & .00284 & 2.66 & 160 & 20 \\
\hline Radius & .03153 & 0.98 & 151 & 19 & .00754 & 2.72 & 160 & 20 \\
\hline \multicolumn{9}{|l|}{ Bolivia } \\
\hline Kernel & .04883 & 1.06 & 88 & 11 & .01181 & 2.91 & 90 & 5 \\
\hline $\begin{array}{l}3 \text { Nearest } \\
\text { Neighbours }\end{array}$ & .04883 & 1.15 & 88 & 11 & .01181 & 2.91 & 90 & 5 \\
\hline Radius & .04883 & 1.08 & 88 & 11 & .01181 & 2.91 & 90 & 5 \\
\hline \multicolumn{9}{|l|}{ Chile } \\
\hline Kernel & .86167 & 1.00 & 89 & 10 & -.0069 & -0.84 & 107 & 13 \\
\hline $\begin{array}{l}3 \text { Nearest } \\
\text { Neighbours }\end{array}$ & .8616 & 0.99 & 89 & 10 & -.0074 & -0.85 & 107 & 13 \\
\hline Radius & .86167 & 1.00 & 89 & 10 & -.0059 & -0.73 & 107 & 13 \\
\hline \multicolumn{9}{|l|}{ Colombia } \\
\hline Kernel & .03460 & -0.01 & 90 & 2 & .0152 & 1.03 & 90 & 2 \\
\hline $\begin{array}{l}3 \text { Nearest } \\
\text { Neighbours }\end{array}$ & .03460 & -0.01 & 90 & 2 & .0152 & 1.03 & 90 & 2 \\
\hline Radius & .0346 & -0.01 & 90 & 2 & .01523 & 1.03 & 90 & 2 \\
\hline \multicolumn{9}{|l|}{ Ecuador } \\
\hline Kernel & .0412 & 1.73 & 123 & 3 & .0175 & 1.16 & 113 & 2 \\
\hline $\begin{array}{l}3 \text { Nearest } \\
\text { Neighbours }\end{array}$ & .0412 & 1.74 & 123 & 3 & .0175 & 1.16 & 113 & 2 \\
\hline Radius & .0412 & 1.74 & 123 & 3 & .0175 & 1.16 & 113 & 2 \\
\hline \multicolumn{9}{|l|}{ Mexico } \\
\hline Kernel & .03584 & 1.85 & 91 & 3 & .00402 & 1.54 & 101 & 3 \\
\hline $\begin{array}{l}3 \text { Nearest } \\
\text { Neighbours }\end{array}$ & .03584 & 2.53 & 91 & 3 & .00684 & 1.74 & 101 & 3 \\
\hline Radius & .03584 & 2.53 & 91 & 3 & .00684 & 1.74 & 101 & 3 \\
\hline
\end{tabular}

The outcome variable in panel A is the share of total RnD to sales. The outcome variable in panel B is the share to RnD to third Party to Sales. In both panels matching is based on firm age, export orientation, capital and employment. 
